\title{
Consideration and the Formation Defenses
}

\author{
Val Ricks*
}

The common law defenses to contract formation-duress, misrepresentation or fraud, mistake, and unconscionability - are best justified historically, doctrinally, logically, and from the standpoint of policy, as a response to the plaintiff's showing of consideration. The next-best alternative, assent, justifies too little.

This thesis is proved in two parts. Part I addresses doctrinal history. The defenses existed in the law long before assent became part of the doctrine. When the defenses developed, consideration was with promise the primary touchstone of contractual liability. The formation defenses were often formulated explicitly with reference to the doctrine of consideration, a facet of the defenses that continues in many statements of them today.

Part II addresses logic and policy. Part II.A begins with a discussion of the policy grounds for the consideration doctrine and, incidentally, defends the doctrine. Part II.B shows the logical, doctrinal, and policy coincidence of consideration and the defenses. The defenses all show more than lack of assent, but they fully respond to, and coincide conceptually with, the plaintiff's allegation of consideration. Part III briefly concludes.

This Article is the second of two addressing the primacy of consideration and the resultant superfluity of assent doctrines in contract formation law. The first article, Assent Is Not an Element of Contract Formation, ${ }^{1}$ showed that assent as an element of formation merely

* Professor of Law, South Texas College of Law. The author wishes to thank participants at the 7th Annual International Conference on Contracts, at Thomas Jefferson School of Law, San Diego, March 2012. The author wishes in particular to thank, for discussions of the paper's arguments, Gabriel Aitsebaomo, Dan Burk, Charles Calleros, Miriam Cherry, Okezie Chukwumerije, Robert Farrell, Mark Gergen, Victor Goldberg, Jack Graves, Richard Harris, Hila Keren, Thomas Kleven, Tadas Klimas, Phillip Page, Deanna Pollard Sacks, Gordon Smith, Steve Ware, Darnell Weeden, and Debra Zalesne. Thanks also to John Baker, Allan Farnsworth, David Ibbetson, Karl Llewellyn, Joe Perillo, Elizabeth Ricks, A.W. Brian Simpson, Ludwig Wittgenstein, and the approximately fourteen hundred former students in the author's Contracts I classes from 1998-2012.

1. Val Ricks, 61 U. KAN. L. REV. 591 (2012). 
duplicates a function already performed by the doctrine of consideration. One can have assent without consideration, but one cannot have consideration without assent. ${ }^{2}$ Because consideration is required, assent was and is already required as part of the consideration analysis. There is therefore no need for a separate element of assent. The first paper shows that the assent doctrines' true function is merely to determine when consideration was given; the assent doctrines show the time of formation when that is important, not whether formation occurred. ${ }^{3}$

This second article shows the doctrinal and conceptual primacy of consideration and resultant superfluity of assent doctrine with respect to the formation defenses. Commentators commonly suggest that the formation defenses exist because they undercut assent. This assertion is made with regard to each defense-duress, ${ }^{4}$ misrepresentation, ${ }^{5}$ mistake, ${ }^{6}$ and even unconscionability. ${ }^{7}$ Fortunately, this mistake is not universal. ${ }^{8}$

I am not claiming that the defenses do not undercut assent. They do. A primary point of Assent Is Not an Element of Contract Formation is that consideration, as both a concept and a legal doctrine, includes assent. One cannot have consideration without assent. Duress and misrepresentation or fraud, for example, undercut assent not just in

2. Id. at 593-94 \& passim.

3. Id. at 591 \& passim.

4. See Restatement (SeCOnd) OF Contracts $\$ \S 174,174 \mathrm{cmt}$. a (1981). The Restatement's phrase for this is "not effective as a manifestation of assent." Id. § 174. Williston holds likewise, as do Farnsworth, Fried, and Murray. 28 SAMUEL WILLISTON \& RICHARD A. LORD, THE LAW OF CONTRACTS $§ 71: 8$ (4th ed. 2003); 1 E. Allan FARNSWORTH, FarnSWORTH ON Contracts $§ 4.16$ (3d ed. 2004); Charles Fried, Contract As Promise 93-103 (1981); John EDWARD MuRRAY, JR., MuRRAY ON CONTRACTS $§ 93$ (4th ed. 2001).

5. See Restatement (SECOND) OF CONTRACTS $§ \S 163,163 \mathrm{cmt}$. a (1981); 28 Williston \& LORD, supra note 4, § 71:8; 1 FARNSWORTH, supra note 4, § 4.10; MURRAY, supra note 4, § 92.

6. See 27 Williston \& LORD, supra note 4, § 70:10 ("no mutuality of assent (i.e., no 'meeting of the minds')"); Oliver Wendell Holmes, THe COMmON LAW 315 (1909) (justifying fraud, misrepresentation, and mistake on lack of assent). This approach is not unanimous. The Restatement (Second) justifies relief for mutual mistake on "the notion of an unexpected material imbalance in the exchange." RESTATEMENT (SECOND) OF CONTRACTS ch. 6, intro. note (1981).

7. See MurRaY, supra note $4, \S 92$. Unconscionability is (perhaps more) often grouped with doctrines policing "Fairness and the Public Interest." Restatement (SECOND) OF Contracts ch. 9, topic 2 (1981); 8 WILLISTON \& LORD, supra note 4, § 18:7; MURRAY, supra note 4 (grouping unconscionability with illegal bargains); see also Melissa T. Lonegrass, Finding Room for Fairness in Formalism-The Sliding Scale Approach to Unconscionability, 44 LoY. U. CHI. L.J. 1, 22-24 (2012) (also reporting judicial opinions analyzing unconscionability as centered on assent).

8. Richard Epstein justified the formation defenses on the ground that each defense, when applicable, undercuts any assumption that the parties will gain from the transaction. RICHARD A. EPSTEIN, SimPle Rules FOR A COMPLEX WORLD 80-82 (1995), cited with approval in JOSEPH M. Perillo, CAlamari AND Perillo on Contracts $§ 9.1$ (6th ed. 2009). 
contract law but also in other areas of the law. ${ }^{9}$ Inasmuch as duress and misrepresentation undercut assent, they also undercut consideration. But as the defenses are phrased and as they function in contract law, they undercut more than assent. Assent therefore does not "occup[y] the entire area" 10 it is said to cover. It fails to exercise "normative authority over" 11 the defenses. It therefore does not "in fact function[] as a justification" 12 for the formation defenses. Something other than assent shapes the defenses' form and function. That something else is consideration.

These conclusions combined with the historical, doctrinal, and logical arguments presented in Assent Is Not an Element of Contract Formation show that, of assent and consideration, consideration is elemental. Assent, on the other hand, is not elemental but is subordinate and dependent on the consideration doctrine.

\section{DEFENSES TO FORMATION: DOCTRINE AND HISTORY}

Assent is a late and subordinate addition to contract formation doctrine. Whereas consideration debuted in assumpsit actions in $1539,{ }^{13}$ assent appeared only in $1818 .{ }^{14}$ Consistent with the mistaken assumption that the formation defenses are justified as undercutting assent, historians have at times also implied that the defenses arose as responses to assent, and late in the game. ${ }^{15}$ However, each was in fact a defense, in law or

9. See, e.g., People v. Morrison, 39 Cal. Rptr. 874, 879 (Cal. Ct. App. 1964) (affirming a kidnapping jury instruction holding that "where one assents to accompany another due to duress, fear or threats of bodily harm, the person so assenting is not considered to be exercising his or her own free will, and the crime of kidnapping may lie"); RESTATEMENT OF TORTS $§ 252$ (1934). Hat tip to Mark Gergen for this point.

10. Ernest J. Weinrib, Legal Formalism, in A COMPANION TO PHILOSOPHY OF LAW AND LEGAL THEORY 332, 334 (Dennis Patterson ed., 1999).

11. Id.

12. $I d$.

13. See David Ibbetson, Assumpsit and Debt in the Early Sixteenth Century: The Origins of the Indebitatus Count, 41 C.L.J. 142, 143 (1982).

14. Ricks, supra note 1, at 604-20; A.W.B. SIMPSON, Innovation in Nineteenth Century Contract Law, reprinted in LEGAL THEORY AND LEGAL HISTORY: ESSAYS ON THE COMMON LAW 171, 182-86 (1987).

15. E.g., A.W.B. Simpson, A History of the COMmon LAW of CONTRACT: THE Rise OF THE ACTION OF ASSUMPSIT 535 (1975) ("The idea that mistake could form an independent ground for invalidity belongs to the nineteenth century, when the theory of consensus ad idem, the meeting of minds, held sway."); James Gordley, The Common Law in the Twentieth Century: Some Unfinished Business, 88 CALIF. L. REV. 1815, 1847-48 (2000) (“A.W.B. Simpson and I have shown that these doctrines were unknown to the earlier common law, and were borrowed, sometimes word-for-word, from continental authors."). Gordley mistakenly assumes that the English common law borrowed 
equity or both, to a promise and consideration in assumpsit long before assent became part of contract law in the early 1800 s.

\section{A. Duress}

Duress has a history in English law stretching at least back to Bracton (circa 1210-1268 CE). ${ }^{16}$ It was a defense even to an action for debt on a bond before 1500 and remained so. ${ }^{17}$ Though there is little evidence of a plea of the defense of duress in the law and operation of assumpsit cases, ${ }^{18}$ Simpson suggests "the explanation may be that if the defendant wished to contend that he promised because of a threat or because of imprisonment his proper course would be to plead the general issue and give the circumstances in evidence as showing the promise was devoid of consideration."19 I have found some proof of this. In Stanton v. Suliard, ${ }^{20}$ a successful litigant promised the Sheriff of Essex that he

them only later. In fact, the ideas crop up fairly frequently in the English legal system that dealt with enforcing promises, at least from the mid-1500s onward, the period covered by this paper. That they were unknown is an overstatement. They had not reached their twentieth-century point of evolution, certainly.

16. 2 Henrici De BRacton, On the Laws and Customs of England 288 (George E. Woodbine ed., Samuel E. Thorne trans., 1968) (1569), available at http://bracton.law.harvard.edu/Common/SearchPage.htm (last visited Nov. 22, 2013).

17. VI SIR JOHN BAKER, THE OXFORD HISTORY OF THE LAWS OF ENGLAND 1483-1558, at 829 (2003); SIMPSON, supra note 15, at 99. The common law includes numerous early instances of duress being used to escape debt on a bond. See, e.g., Martin v. Cole, (1734) 24 Eng. Rep. 1070, 1072 (Ch.), 3 P. Wms. 290, 295 ("A man was caught in bed with another's wife; and the husband who caught him, having a sword in his hand, was about to kill the man, who was naked, and in the power of the husband. But upon the man's desiring the husband not to take that advantage of him, and saying, that he would make him reparation; thereupon they went into another room, where the man gave the husband a note for $£ 100$ payable at certain time. After which, the money growing due, the husband came for payment; and the man excusing payment, gave his bond for the money, and afterwards brought his bill to be relieved. The Lord Cowper declared, that if the matter had rested on the note, which was gained by a man armed, from one naked, and by duress, though it happened to be given in satisfaction for the greatest injury (in which case, however, the utmost remedy the law would have given had been damages to be ascertained by a jury), he should have made no difficulty of granting relief; but when afterwards the plaintiff had coolly, and without any pretence of fear or duress, entered into a bond to the husband, he had thereby himself ascertained the damages, and ought not to be relieved.");Woodman v. Skuse, (1708) 22 Eng. Rep. 157, 158 (Ch.), 2 Eq. Cases Abr. 183, 184 (also reported at 25 Eng. Rep. 7, Gilb. Rep. 9) (attributing to Lord Cowper (d. 1723) the following: "Lord Cowper declared that if the Matter had rested on the Note which was gained by a Man armed from one naked, and by Duress, tho' it happened to be given in Satisfaction for the greatest Injury (in which Case, however, the utmost Remedy the Law would have given $B$. had been Damages to be ascertained by a Jury), he should have made no Difficulty of granting Relief ...."); Huscombe v. Standing, (1607) 79 Eng. Rep. 163, Cro. Jac. 187 (dicta).

18. SimPSON, supra note 15, at 537.

19. Id.

20. (1599) 78 Eng. Rep. 893 (Ex. Ch.), Cro. Eliz. 654. 
would pay the Sheriff a certain statutory fee if the Sheriff would levy an execution. ${ }^{21}$ The Sheriff executed, and when the litigant did not pay the fee, the Sheriff sued in assumpsit. ${ }^{22}$ The litigant pleaded the general plea in denial, non assumpsit, and when the Sheriff won at trial, the litigant appealed on the grounds "there was not any sufficient consideration[,] for" having to pay a public official to do his job was extortion. ${ }^{23}$ One Justice, Glanville, agreed, but no one else did. ${ }^{24}$ The other judges reasoned that, because the Sheriff could legally take the fee, the Sheriff therefore could legally take a promise for the fee. ${ }^{25}$ No one argued that extortion did not belong under the general plea, however. I have found two other, similar cases from the same time period. ${ }^{26}$

Much more interesting is Ricord v. Bettenham (1765). ${ }^{27}$ Bettenham was captain of the British ship "Syren," and Ricord captain of the French privateer "Badine." 28 Britain and France were at war. ${ }^{29}$ The Badine captured the Syren, took its first mate hostage, and held the Syren for ransom. ${ }^{30}$ The Syren was on a schedule, and in order to get the ship back and make its next port, Bettenham "obliged himself and owners to pay" the ransom amount equal to $236 l .^{31}$ Ricord took Bettenham's note and let the Syren go. ${ }^{32}$ The Syren made port. ${ }^{33}$ Ricord later made his way to Britain and sued Bettenham on his promise. ${ }^{34}$ Bettenham pleaded non assumpsit. ${ }^{35}$ Ricord's attorney, who argued first, argued against duress. ${ }^{36}$

\footnotetext{
21. Id. at 893.

22. $I d$.

23. Id.

24. Id.

25. Id. Justice Glanville had a decent argument. See Sherley v. Packer, (1616) 81 Eng. Rep. 509, 510 (K.B.), 1 Rolle. 313, 314 (finding consideration paid to a sheriff invalid because a statute provided "que nul viscount prendera ascun deniers pur server de proces, $\&$ pur ceo le receiver de ceux deniers est extortion").

26. Both cases involve discussion of the statutory rights of sheriffs to a fee and whether some duress, hardship, or extortion render the promise of a fee not actionable. All of the discussion takes place on appeal of a trespass on the case in assumpsit for lack of consideration. See Bath v. Salter, (1625) 73 Eng. Rep. 1009 (K.B.), Benl. 138, 73 Eng. Rep. 1015, Benl. 147; Sherley, 81 Eng. Rep. at 509-10.

27. (1765) 96 Eng. Rep. 326 (K.B.), 1 Black. W. 563.

28. Id. at 326 .

29. Id.

30. Id.

31. Id.

32. Id.

33. Id.

34. Id.

35. Id.

36. Id.
} 
Bettenham's attorney, however, waived the duress issue. ${ }^{37}$ But no one argued that duress was improper on the general plea. ${ }^{38}$ Much later, in the United States, evidence that a duress defense was available after a defensive plea of non assumpsit became more explicit. ${ }^{39}$

Sheppard put a limitation on promise enforcement this way in his 1663 treatise on actions on the case:

If I arrest a man, to the end hee should ingage himself to mee, for mony, where none is due, and hee being in prison, doth so, so that the promise is made by Duresse of Imprisonment; this is void. . . . [I]f one threaten to kill, beat, wound, or imprison mee, unlesse I will make him such a promise, and thereupon, and for this cause onely, I do it, let the promise be made to him that both threaten mee, or to another, it is void, and the Action brought upon it may be avoided for this. But the threatning of mee to kill, beat, wound, or imprison my Father, Mother, Childe, Brother, Sister, or friend; or the threatning of mee to burn my house, enter upon my Land, or take away my goods, will not make such a Contract void.

It was a harsh world, but that does not mean every promise was enforceable.

On the flip side, courts also decided long before assent became part of the law that an action in a form of assumpsit, specifically indebitatus assumpsit for money had and received, ${ }^{41}$ was available to recover

37. Id. at 327 .

38. Blackstone was co-counsel for the defense. Id. at 328. When Lord Mansfield C.J. expressed doubts about how to rule, Blackstone offered to inquire whether France and Holland would entertain such an action. Id. Mansfield took him up on the offer, and Blackstone later reported that all the foreign lawyers he talked to said their countries would allow it. Id. Mansfield then said, "I imagined the enquiry would turn out as it has done." Id. He then ruled for the plaintiff: "Justice ought in time of war to be administered to foreigners in our Courts in the most extensive and liberal manner, because the Crown cannot here interpose, as it can in absolute monarchies, to compel the subject to do justice, in an extrajudicial manner." Id.

39. See counsel's argument in Moore v. Ex'rs of Moore, 1 N.J.L. 363, 373, 1795 WL 593 (N.J. Sup. Ct. 1795) ("Under the plea of non assumpsit anything which shows that ex equo et bono, the plaintiff is not entitled to recover, may be given in evidence, as payment, usury, duress, nonage, \&c."); see, e.g., Bell v. Adm'rs of Wood, 1 S.C.L. (1 Bay) 247, 1792 WL 206 (1792) ("It came out from the evidence in this case" in assumpsit that the promise was made under duress, justifying a jury verdict for the defendants.).

40. William ShEPPARD, ACTIONS UPON THE CASE FOR DEEDS, VIZ. CONTRACTS, ASSUMPSITS, Deceipts, Nusances, Trover and Conversion, Delivery of GOOdS, AND For OTHER MALEFEASANCE AND MIS-FEASANCE 90 (London, 1663) (citations omitted).

41. The action for indebitatus assumpsit for money had and received was regular by 1610. See, e.g., Rooke v. Rooke, (1610) 79 Eng. Rep. 210, Cro. Jac. 245, 80 Eng. Rep. 117, Yel. 175; J.H. Baker, The History of Quasi-Contract in English Law, in Restitution: PAST, PRESENT \& Future 37, 44 (W.R. Cornish et al. eds., 1998). 
damages against someone who had extorted money by duress. In Astley $v$. Reynolds,${ }^{42}$ the plaintiff pawned goods for $20 l$. and after three years came to redeem them. ${ }^{43}$ The defendant requested $10 l$. interest, a usurious amount. ${ }^{44}$ The plaintiff tendered $4 l$., and when the defendant refused to give up the goods, the plaintiff gave $10 l$. and sued in indebitatus assumpsit for money had and received. ${ }^{45}$ The court granted relief, saying, per curiam, "[T] his is a payment by compulsion ...."46 It would be amazing if the law courts allowed money to be recovered in indebitatus assumpsit that was paid under duress but forced the payment of damages for breach of a promise made under the same duress to pay the same money.

Finally, the chancery, which followed consideration doctrine, ${ }^{47}$ might grant relief for duress in actions based on agreement. ${ }^{48}$ It seems clear

42. (1733) 93 Eng. Rep. 939 (K.B.), 2 Str. 915.

43. Id. at 939 .

44. Id.

45. $I d$.

46. Id. The report at 94 Eng. Rep. 343, 343-44, 2 Barn. K.B. 40, 41-42, has only Raymond, C.J., agreeing with the duress rationale, and one judge dissenting, but states that they held over for argument another day and later gave the plaintiff judgment. It is possible that Strange reported the later decision.

47. See 21 Eng. Rep. 148 (Ch.), Toth. 141 ("The opinion of the Court was, the plaintiff having but a promise, could have no decree for the land, yet it might be decreed that the defendant might assure the land, Ferne contra Bullock, decreed upon a promise, and ten shillings in hand to assure, in Nov. 9 Jac. [1611]."); 21 Eng. Rep. 155 (Ch.), Toth. 162 ("Ferne contra Bullock, Mich. 9 Jac. li. A. fo. 274 [1611], the defendant promised to sell the plaintiff land, whereof ten shillings was given him, yet the defendant would not perform, yet he should."); 21 Eng. Rep. 154 (Ch.), Toth. 159 ("Standen contra Bullock, the plaintiff bought several manors of Thomas Bullock, deceased, who (before the plaintiff's purchase) had conveyed the same by fine and recovery to the defendant and his heirs males, which being done without consideration, was adjudged and decreed to the Plaintiff, in 38 Eliz. li. A. fo. 713 [1595-96], and 42 Eliz. li. B. fo. 289 [1599-1600] . . . "); Anonymous, 21 Eng. Rep. 3, 3 (Ch.), Cary 5, 5 ("Upon nudum pactum there ought to be no more help in Chancery than there is at the common law, neither against him that hath waged his law in debt, though peradventure falsely."); Anonymous, 21 Eng. Rep. 5, 5 (Ch.), Cary 9, 9 (“A delivereth twenty pounds to B to the use of $\mathrm{C}$, a woman, to be delivered her the day of her marriage. Before her marriage, A countermandeth it, and calleth home the money. C shall not be aided in Chancery, because there is no consideration why she should have it (Dyer, 49).").

48. See, e.g., Moore v. Moore, (1716) 22 Eng. Rep. 22, 23 (Ch.), 2 Eq. Cas. Abr. 26, 26 (reporting a nine-hour trial on the duress issue); Mulsoe v. Montague, (1680-81) 79 SELDEN SoC. 852 (case no. 1068) (Ch.); 21 Eng. Rep. 106 (Ch.), Toth. 4 ("Plowden contra Marsham, if agreement be compelled by threats, it shall not bind, in Hil. 3 Cat. [1628], look 10th of June 1602, the contrary between lord and tenant."); de York v. Crop, (1337) 10 SELDEN Soc. 127 (case no. 134) (Ch.) (petition for relief from bonds on ground of duress by imprisonment); $c f$. Woodman v. Skuse, (1708) 25 Eng. Rep. 7,7 (Ch.), Gilb. Rep. 9, 9 (Cowper, Ch., in dicta, after examining the facts, which showed the cool-headed affirmation of the promise after the fact: "If a Jury in this Case had given Damages, this Court could not relieve."); 21 Eng. Rep. 158 (Ch.), Toth. 170 ("Maneright contra Roberts, a man relieved against his own deed, the same being gotten by threats and practice, though the same be vested in an infant, and the purchaser to become bound in recognizance to assure it, 
that, in the minds of the lawyers who invented the consideration doctrine, and their successors, duress was either a factual showing that indicated no consideration existed or a defense to an action on facts that would have been brought on the case for assumpsit. At any rate, duress appears firmly established as a defense in the minds of those lawyers who practiced contract law from the time consideration was required until the time assent was added conceptually, and duress appears for all we can see to render a promise unenforceable. ${ }^{49}$

\section{B. Misrepresentation or Fraud}

Misrepresentation or fraud has a similar history, just as old ${ }^{50}$ though the evidence is more apparent in the time period in which consideration became the touchstone of relief in assumpsit. Relief was available for misrepresentation, and the evidence demonstrates that the common lawyers had integrated misrepresentation or deceit into how they handled assumpsit claims.

First, proof of misrepresentation was apparently admissible by a defendant on a plea of non assumpsit, just as was proof of duress. In a case decided around 1600, Collins's daughter wanted to marry $\mathrm{Mr}$. Wills. ${ }^{51}$ Collins promised Wills $80 l$. in marriage and no more, but Wills wanted $90 l^{52}$ The daughter then, in consideration that Collins would give Wills another $10 l$., promised to return it to Collins after the marriage. ${ }^{53}$ Collins gave Wills $90 l$., and the marriage occurred. ${ }^{54}$ Then Wills refused to give back the $10 l$., and apparently his wife did not give it back, either. ${ }^{55}$ So Collins brought an action on the case in assumpsit against Wills for his wife's promise. ${ }^{56}$ Wills pleaded non assumpsit, and a jury found against him, but on appeal Wills argued "that this was an insufficient and unlawful consideration to ground this action, and made only in deceit of the defendant, who was her husband.-And of that

when, \&c., in 10 Jac. [1612-13].”).

49. Duress's near cousin, undue influence, a doctrine that applies not just to contracts but all kinds of juridical acts, was also developed soon after the consideration doctrine. The doctrine is often attributed to Joy v. Bannister (Ch. 1617), reported in REPORTS OF CASES DECIDED BY FRANCIS BACON 33 (John Ritchie ed., 1932).

50. See BRACTON, supra note 16 .

51. Collins v. Wills, (1600) 78 Eng. Rep. 1004, 1004 (K.B.), Cro. Eliz. 774, 774.

52. Id.

53. $I d$.

54. Id.

55. Id.

56. Id. 
opinion was the whole Court ....57 This is a somewhat unorthodox fraud claim, but that is probably why it was the subject of a report. If evidence of misrepresentation was admissible on a general plea of non assumpsit, then the misrepresentation issue would go to the jury, and no other report or evidence of a garden-variety misrepresentation defense would be available.

Sheppard later put a case this way:

If I sell my horse first to one, on condition that hee pay mee five pound such a day, and before the day I sell him to another; this second Contract seems to be void, albeit I bee not paid my five pound, and that I seize him again, and therefore the first Contract is good. And a man may not sell that which is none of his own. ${ }^{58}$

But of course, one actually may sell that which is not his own, because he may buy it before delivery is due. ${ }^{59}$ The problem in this case appears to be the deceit.

Second, the assumpsit action itself was in part based on an allegation of deceit. Baker records the evolution of the typical assumpsit pleading. Early on, the assumpsit pleading form alleged an undertaking to perform an act in return for money, and a failure to act. ${ }^{60}$ Over time, the pleading form split the bargain and the promise into separate clauses, alleged separate consequential damages flowing from the breach of promise itself, and concluded with "a general allegation of deceit and injurious reliance." ${ }^{, 61}$ The model for this, as Baker notes, was Doige's Case, ${ }^{62}$ which alleged an actual act of misfeasance that disabled the promisor from performing (the land vendor enfeoffed someone other than the

57. Id.; see also 1 Rolle. (reporting the case c. 1600) (“car le consideracion n'est bon, mes le promise fuit fraudulent \& covenous"). Collins perhaps sat around a bit while the judges decided what to do with it. See Collins v. Wills, (c. 1597) 72 Eng. Rep. 701, 701 (K.B.), Moo. K.B. 468, 468 (suggestion of Popham, C.J., that the defendant could alternately have pleaded the deceit); Collins v. Wills, (c. 1597) 74 Eng. Rep. 901, 901 (K.B.), Ow. 63, 63 (Popham, C.J.'s opining that the consideration was void, against the opinion of Gawdy, J., and Fenner, J., who believed the action maintainable).

58. SHEPPARD, supra note 40 , at 78 ; see also id. at 35 .

59. This appears to be the meaning of another case Sheppard cites, where I sell two horses together, my own and another's, and the other takes his horse before the purchaser pays the money. $I d$. at 35. Sheppard specified that I may recover the money but the purchaser may sue me afterward for deceit. Id.

60. BAKER, supra note 17 , at 850 .

61. Id. at 851 .

62. Shipton v. Dog, (1440) K.B. roll, Trin. 18 Hen. V, K.B. 27/717, m. 111, London, reported in A.K.R. KIRALFY, A SOURCE BOOK OF ENGLISH LAW 192-93 (1957) (Kiralfy's translation of the pleadings in the case). 
promisee). ${ }^{63}$ But if the deceit allegation helped at all, it would also help in a pure nonfeasance case, where it was afterward alleged. ${ }^{64}$ In fact, it was common feeling at the time that the extension of trespass to breach of promise occurred in part because of the deceit allegation. ${ }^{65}$ Thus, promises that were deceitful in themselves could be remedied in assumpsit cases.

Third, even beyond fraudulent promises, some misrepresentation was itself actionable in assumpsit. In Chandelor v. Lopus, ${ }^{66}$ the defendant, a goldsmith, "affirmed to Lopus [that a certain stone was] a bezar-stone, and sold it to him for one hundred pounds; [but] it was not a bezarstone...."67 The plaintiff won a verdict, but on appeal the Exchequer Chamber, all the common law judges save one agreeing, reversed. ${ }^{68}$ "[T]he bare affirmation that it was a bezar-stone, without warranting it to be so, is no cause of action: and although he knew it to be no bezarstone, it is not material...." ${ }^{99}$ The report assures, however, that had Chandelor warranted that it was a bezar-stone at the time of the sale, Lopus would have succeeded in an action on the case. ${ }^{70}$ Sheppard lists

63. See id.; J.H. BAKER \& S.F.C. Milsom, SOURCES OF English LEGAL History: Private LAW TO 1750, at 390 (1986) (summarizing the pleading); see also the pleading in Orwell v. Mortoft (C.P. 1505), id. at 406, which alleged that the defendant, "scheming fraudulently and craftily to defraud the said Thomas, wholly converted the aforesaid 60 quarters of barley to his own use and did not deliver it within the aforesaid time."

64. See, e.g., Slade's Case, (1602) 76 Eng. Rep. 1072, 1072 (K.B.), 4 Co. Rep. 91a, 91b (alleging defendant acted "subtilly and craftily to deceive and defraud"); Gower v. Capper, (1597) 78 Eng. Rep. 790, 790 (K.B.), Cro. Eliz. 543, 544 (a mutual promise case in which the plaintiff alleged that the defendant produced inadequate performance, "intending to deceive"); Bretton v. Bolton, (1592) 78 Eng. Rep. 501, 502, Cro. Eliz. 246, 247 (“[D]efendant falsely and maliciously deceived ... plaintiff ...."); see also Pykeryng v. Thurgoode, (1532) 94 SELDEN Soc. 247, 248 (K.B.) ("machinans").

65. See Pinchon's Case, (1611) 77 Eng. Rep. 859, 863, 9 Co. Rep. 86b, 89a (Coke reports all the judges agreeing "in respect that the breach of promise is alledged to be mixed with fraud and deceit to the special prejudice of the plaintiff, and for that reason it is called trespass on the case."); Kirkby v. Coles, (1589) 78 Eng. Rep. 394, 394 (K.B.), Cro. Eliz. 137, 138 (Wray, C.J., and Clench, J.'s asserting "the action was grounded upon the promise and deceit").

66. (1602) 79 Eng. Rep. 3, (Ex. Ch.), Cro. Jac. 4.

67. Id. at 3-4.

68. Id. at 4. Anderson, J., disagreed. Id.

69. Id. The judgment was not free of doubt. Popham, C.J., kept the case under argument until at least 1606, claiming that scienter, not warranty, made the difference. Chandelor v. Lopus, as reported in BAKER \& MILSOM, supra note 63, at 518, 521-22; see also Kenrick v. Burges, (1583) 72 Eng. Rep. 483 (K.B.), Moo. K.B. 126 (supporting Popham's position).

70. Chandelor, 79 Eng. Rep. at 4. See also Harvey v. Yonge, (1602) 80 Eng. Rep. 15 (K.B.), Yel. 21, as reported in SIMPSON, supra note 15, at 639 ("And it was held that an action does not lie ... on the naked assertion of S . . . But it would be otherwise if $\mathrm{S}$ had warranted the term to be of such value, for the warranty is a means of inducing confidence."); SIMPSON, supra note 15, at 535-37 (discussing the evolution of the "old action for deceit for breach of warranty ... in 
numerous cases of misrepresentation actionable as breach of warranty in assumpsit. $^{71}$

And beyond breach of warranty, misrepresentation became a ground fairly early for an action for money had and received, another case of indebitatus assumpsit. ${ }^{72}$ For example, in Cross v. Gardner, ${ }^{73}$ a seller possessed certain oxen. ${ }^{74}$ After a conversation in which the seller claimed to own the oxen, the buyer agreed to buy them and paid the price. $^{75}$ Later, however, the real owner of the oxen repossessed them. ${ }^{76}$ The buyer then sued the seller in assumpsit for deceit. ${ }^{77}$ The court held for the plaintiff notwithstanding there was no warranty. ${ }^{78}$

This development, combined with the notion that the general assumpsit action was grounded in deceit, allowed Lord Mansfield to declare in 1760 ,

If one man takes another's money to do a thing, and refuses to do it; it is a fraud: and it is at the election of the party injured, either to affirm the agreement, by bringing an action for the non-performance of it; or to disaffirm the agreement ab initio, by reason of the fraud, and bring an action for money had and received to his use. ${ }^{79}$

Notice the tie to consideration: Fraud occurs when one "takes another's money to do a thing." It is when the promise given for consideration is not accomplished that the fraud label is imposed. In this way assumpsit was a kind of action for deceit.

And, as Mansfield noted, fraud or deceit had become a ground for recovery of money in indebitatus assumpsit. ${ }^{80}$ As with duress, it would

connection with the contract of sale").

71. SHEPPARD, supra note 40, at 105-08.

72. E.g., Lady Cavendish v. Middleton, (1628) 79 Eng. Rep. 725 (K.B.), Cro, Car. 141, 82 Eng. Rep. 104, Jones, W. 196 (allowing the action to recover a payment of money induced by misrepresentation); see also Kenrick v. Burges, (1583) 72 Eng. Rep. 483, 484 (K.B.), Moo. K.B. 126, 127 ("Auxi le Court ceo prist que accon sur le case gist en nature de disceit.... Mes Tho. Gawdy dit que le accon ne gist, si non que il alleage que le def. sciens . . ..”).

73. (1689) 89 Eng. Rep. 453 (K.B.), 1 Shower, K.B. 68.

74. Id. at 453 .

75. Id.

76. Id.

77. Id.

78. Id. at 454; see also SHEPPARD, supra note 40, at 107-08 (listing other cases).

79. Moses v. Macferlan, (1761) 97 Eng. Rep. 676, 680 (K.B.), 2 Burr. 1005, 1011.

80. See Astley v. Reynolds, (1733) 93 Eng. Rep. 939, 939 (K.B.), 2 Str. 915, 916 (“[P]er Curiam, the cases of payments by mistake or deceit, are not to be disputed ...."); Tomkyns v. Barnet, (1694) 90 Eng. Rep. 182, 182-83 (K.B.), Skin. 411, 411-12 (Holt, C.J.) (opining that relief should be granted against and "upon a fraud in the receiver"); Tomkins v. Bernet, (1693) 91 Eng. 
have made little sense to grant recovery for money obtained by fraud but to enforce a promise obtained by fraud to pay money.

Finally, as it did with duress, the Chancery granted relief for fraud. ${ }^{81}$ It is difficult to know whether the Chancery ordered rescission ${ }^{82}$ or

Rep. 21, 21 (C.P.), 1 Salk. 22, 22 ("Treby C.J. allowed, that . . . where one pays money under or by a mere deceit, it is reasonable he should have his money again ....").

81. See, e.g., Jarvis v. Duke, (1681) 23 Eng. Rep. 274, 274 (Ch.), 1 Vern. 19, 19 ("[I]t was said by my Lord Chancellor, that it is the constant rule, where there is either suppressio veri or suggestio falsi, the release shall be avoided."); 21 Eng. Rep. 157, Toth. 170 ("Tuck contra Pattison, the plaintiff relieved upon a promise against a deed of purchase, there being some, practice in the purchaser, in April, 11 Jac. [1613].”); Flete v. Lynster, (1417-24) 10 SELDEN Soc. 116 (case no. 119) (Ch.) (petition for relief from a purchase agreement for fraudulent inducement); Brampton v. Seymour, (1386) 10 SELDEN Soc. 2 (case no. 2) (Ch.) (petition for relief from a release for fraudulent inducement); 10 SELDEN SoC. xxxiii (Ch.) (listing petitions for relief on grounds of fraud); $c f .21$ Eng. Rep. 158, Toth. 170 ("Maneright contra Roberts, a man relieved against his own deed, the same being gotten by threats and practice, though the same be vested in an infant, and the purchaser to become bound in recognizance to assure it, when, \&c. in 10 Jac. [1612-13].") Fraud was also examinable in the creation of a use. See Anonymous, 21 Eng. Rep. 8, 8, Cary 14, 14 ("If A sell land to B for twenty pounds, with confidence, that it shall be to the use of A, yet A shall have no remedy here, because the bargain hath a consideration in itself (Dyer, 169, per Harper); and such a consideration in an indenture of bargain and sale seemeth not to be examinable, except fraud be objected, because it is an estoppel."); see also, e.g., Joy v. Bannister (Ch. 1967), reported in REPORTS OF CASES DECIDED BY FRANCIS BACON 33 (John Ritchie ed., 1932) (ruling regarding a deed and will obtained "by practice and circumvention").

82. Chancery could order litigation on a promise to cease, which is the functional equivalent of rescission. E.g., Crowder v. Robinson, 21 Eng. Rep. 71, 71 (Ch.), Choyce Cases. 115, 115 ("An Injunction to stay an action at Common Law the suite in this Court having the precedency.-An Injunction was awarded against the defendant, for stay of an Action of the Case upon an Assumpsit by him brought in her Majesties Bench against the plaintiff for or concerning an agreement or contract for a Lease for the which before the plaintiff had exhibited his Bill. Crowder plaintiff, Robinson defendant. Anno 19 \& 20 Eliz. [1577].”); Cotes v. Freston, 21 Eng. Rep. 67, 67 (Ch.), Choyce Cases. 109, 109 ("An Injunction to stay Execution.-A Writ is awarded against the Defendant, his Councellors and Attorneys, that they upon penalty of $£ 100$ shall sue no execution of a Judgement in an Action of debt commenced by the Defendant against the Plaintiff at the common Law, until further order be taken therein by this Court of Chancery. Robert Cotes Clerk Plaintiff, John Freston Defendant. Anno 5 \& 6 P. \& M. [1558].”); Ayland v. Bacon, 21 Eng. Rep. 19, 19 (Ch.), Cary 36, 36 ("An injunction is awarded against the defendant, to stay his proceedings in the Sheriff's Court, of London, or elsewhere, upon debt of one hundred pounds, not to proceed to trial, judgment, or to execution, if judgment be given; John Ayland, plaintiff; Francis Bacon, defendant (Anno 5 \& 6 Philip \& Mary, fol. 29 [1558]).”); Stanebridge v. Hales, 21 Eng. Rep. 24, 24 (Ch.), Cary 45, 45 ("An injunction was granted against the defendant upon pain of one hundred pounds, that he should not prosecute an action of debt of five pounds, or any writ of nisi prius, jury, judgment, or execution of judgment, if judgment be given, before the Justices of either Bench, until special licence be given by this Court: Thomas Stanebridge, plaintant; Thomas Hales defendant (Anno 1 Eliz fol. 103 [1558-59])."). If the injunction was ignored, and judgment was taken, the Chancellor could enjoin the plaintiff to acknowledge satisfaction of that judgment. Colverwell v. Bongey, 21 Eng. Rep. 25, 25 (Ch.), Cary 45, 45-46 ("The defendant, notwithstanding an injunction delivered unto him, got a judgment upon an action of debt in the Common Pleas; and decreed upon the hearing of the cause that the defendant shall within fourteen days next after the decree resort to the record in the Common Pleas, whereupon the said judgment is entered, and there to confess of record a full satisfaction of the said judgment."). 
simply refused to order performance ${ }^{83}$ (if neither was necessary, the Chancery would send the case back to the law $\operatorname{courts}^{84}$ ), but the possibility of relief in Chancery also made fraud part of the rules governing promises.

Clearly, misrepresentation or fraud had a long road of development before it would reach what was later to become our modern misrepresentation defense, pleadable affirmatively in a legal action or the basis for an equitable action for rescission, ${ }^{85}$ but it was also firmly in the minds of lawyers litigating contract disputes long before assent became a doctrinal issue in contract. Not only is there no hint that anyone saw this as a problem to be solved, but it went hand in hand with the assumpsit rules then in force.

\section{Mistake}

Mistake as a defect in contract formation has a long history

83. Chancery had power to order performance. See Arnold v. Barrington, (1631) 21 Eng. Rep. 167, 168 (Ch.), Dick. 5, 6 (ordering specific performance of a promise to convey lands); 21 Eng. Rep. 155 (Ch.), Toth. 163 ("Plaile contra Plaile, the defendant promised to his father to assure certain copyhold lands to the plaintiff, but the father dying before any surrender denied to assure the same, yet decreed he should, 21st May, 9 Jac. [1611]."); id. ("Egerton contra Eldred, the defendant promised to procure a lease of certain lands for the plaintiff, from the contractors, but passed the same to himself, yet ordered and decreed that the same shall be passed to the plaintiff, according to the first agreement, in Feb. 8 Jac. June, 11 Jac. [1611, 1613]."); 21 Eng. Rep. 155 (Ch.), Toth. 162 ("Where the law cannot give a lease, or a thing promised but damage, there is some cause for the Court to compel the party to perform the thing promised, Browne contra North, Waller contra Salter, in Trin. 8 Jac. li. A. [1610]."); id. ("A man promiseth to assure lands in consideration of marriage, but after the marriage refuseth, yet ordered, Gerard's case, in 2 Jac. li. A. fo. 202 [16045]."); id. ("Long contra Long, in 40 Eliz. li. A. fo. 360, or 369 [1597-98], the defendant promised and agreed to assure leases in marriage with the plaintiff's daughters, who would not perform it, but ordered.”); Butler v. Denton, (c. 1582-83) 21 Eng. Rep. 97 (Ch.), Choyce Cases. 166 (order to assure lands according to a bargain and agreement).

84. See Grevill v. Bowker, 21 Eng. Rep. 84, 84 (Ch.), Choyce Cases. 140, 140 ("The suite is for a promise supposed by the Plaintiff to be made to him by the defendant, to yeeld up and surrender a Lease of a pasture and certain tithes upon the payment of 100 Marks by the plaintiff to the defendant, and dismissed upon hearing, as more meet to be decided at the Common Law then [sic] in this Court. Grevill plaintiff, Bowker defendant. Anno 22 Eliz. [1579-80].”); Sutton v. Eringto, 21 Eng. Rep. 84, 84, Choyce Cases. 140, 140-41 (also reported at 21 Eng. Rep. 52, Cary 97) ("Consim. - Sutton Plaintiff, Eringto Defendant, a suit upon a promise, and twelve pence accepted in consideration, referred to the Common Law, Anno 22 Eliz. [1579-80]."). Cary thought this important enough to write down: "Conscience never resisteth the law, nor addeth to it, but only where the law is directly in itself against the law of God, or the law of Reason; for in other things, Equitas sequitur legem (Saint Germaine, fol. 85. 155).” 21 Eng. Rep. 6, Cary 11.

85. See generally DAVID J. IbBETSON, A Historical Introduction to the LAW of OBLIGATIONS 208-11, 234-36, 252 (1999) (discussing the development of fraud); Michael Lobban, Contractual Fraud in Law and Equity, c1750-c1850, 17 O.J.L.S. 441 (1997). 
stretching back to at least the $1600 \mathrm{~s} .{ }^{86}$ It came in fits and starts. In Chandelor v. Lopus (1602), ${ }^{87}$ whether a warranty existed or not, both parties acted on the assumption that the stone was a bezar. ${ }^{88}$ The case suggests the mistaken assumption was irrelevant. But English lawyers were good enough at natural law to know that one could not convey or release something that did not exist, ${ }^{89}$ or promise something that cannot possibly be, ${ }^{90}$ so mistakes as to these things were always exceptions. Moreover, relief from mistake was available in the common law action for account. ${ }^{91}$

As the consideration requirement was maturing in the late $1500 \mathrm{~s}$, courts also began granting relief in actions for indebitatus assumpsit for money had and received, for money paid by mistake. ${ }^{92}$ Eventually, some of these actions not only covered the mutual mistake fact pattern but also illustrate the tie between mistake and consideration. In Martin v. Sitwell $(1691),{ }^{93}$ Barksdale made a policy of assurance, for a $5 l$. premium, supposedly covering goods in Martin's name on board a boat. ${ }^{94}$ At the time, however, Martin had no goods on board. ${ }^{95}$ The court held that "the policy is made originally void, the party for whose use it was made

86. Val D. Ricks, American Mutual Mistake: Half-Civilian Mongrel, Consideration Reincarnate, 58 LA. L. REV. 663, 688-715 (1998).

87. (1602) 79 Eng. Rep. 3 (Ex. Ch.), Cro. Jac. 4.

88. Id. at 3-4, discussed supra text accompanying notes 66-69.

89. Quick v. Ludborrow, (1615) 81 Eng. Rep. 25, 26 (K.B.), 3 Bulst. 29, 30 (also reported at 81 Eng. Rep. 428, 1 Rolle. 196) ("[A] release doth not operate, but upon an estate, interest or right, none of which is here in this case, and therefore the release is void.").

90. JoHn COWELL, THE INSTITUTES OF THE LAWES OF ENGLAND 172-73 (London, 1651) ("If a man promiseth to give a thing which is not in Rerum natura, nor cannot be possibly, it is void, so if one promise that which is not any ones particularly, as a thing sacred or publick."); id. at 174 ("A Covenant is made also invalid, by a condition which is naturally impossible; as if the Covenant be to give me so much if I touch heaven with my finger . . ..").

91. See, e.g., Hewer v. Bartholomew, (1598) 78 Eng. Rep. 855, 856 (K.B.), Cro. Eliz. 614, 614; see also R.M. JACKSON, THE HISTORY OF QUASI-CONTRACT IN ENGLish LAW 6-7 (1936) (discussing action of account cases allowing recovery for money paid by mistake).

92. See Framson v. Delamere, (1595) 78 Eng. Rep. 711, Cro. Eliz. 458; see also, e.g., Tomkyns v. Barnet, (1694) 90 Eng. Rep. 182, 182-83 (K.B.), Skin. 411, 411-12 ("Holt Chief Justice seemed to incline strongly, that it did not lie; . . . and though the case was objected, that if a man pay money upon a policy of assurance, supposing a loss, where there was not any loss, that in such case this shall be money received to the use of the payer; he admitted it, because here the money was paid upon a mistake ... ."); Tomkins v. Bernet, (1693) 91 Eng. Rep. 21, 21 (C.P.), 1 Salk. 22, 22 ("One, bound in a policy of assurance, believing the ship to be lost, when it was not, paid his money; and it was held he might bring an assumpsit for the money ...."); Bonnell v. Fowke, (1657) 82 Eng. Rep. 1224 (K.B.), 2 Sid. 4, also reported in and discussed by Baker, supra note 41, at 50-51.

93. (1691) 90 Eng. Rep. 911 (K.B.), Holt, K.B. 25.

94. Id.

95. Id. at 912 . 
having no goods on board, so that the money was received without any consideration, and consequently received to the plaintiff's use." $" 96$

The Chancery recognized mistake as a ground for relief just as early. Again, there is something unnatural about a promise to convey what does not exist. In a case from $1459,{ }^{97}$ a defendant assigned debts to a plaintiff in return for which plaintiff gave a bond. ${ }^{98}$ The debts, being mere choses in action, were not assignable at this early period. ${ }^{99}$ The Chancery therefore, with the concurrence of the law courts, decided that the bond should be given up as without a quid pro quo. ${ }^{100}$ When the defendant refused to give up the bond, the Chancellor sent him to prison. ${ }^{101}$

In Gee v. Spencer, ${ }^{102}$ over two hundred years later, a man, "being made to believe, that he should be forced to pay costs," released his wife's share of profits from a rectory that were the subject of a lawsuit. ${ }^{103}$ But his belief was mistaken, and the reporter of the case concluded "that a misapprehension in the party shall avoid his release." 104 Other cases are scattered through the 1700s. ${ }^{105}$ By 1737, Henry Ballow could report mistake as a general category warranting equitable relief from agreements. ${ }^{106}$

At any rate, the same lawyers who thought of recovery in assumpsit as grounded on consideration recognized mistake as an exception. Mistake as a ground for relief was established long before assent formally entered the law of contracts. When a fully matured doctrine of mutual mistake emerged in the early 1820s in Virginia, it was about an

96. $I d$.

97. J.R.'s Case, (1459) 37 Hen. VI 13 (Ch.), available with paraphrase in English at http://www.bu.edu/phpbin/lawyearbooks/display.php?id=19278 (last visited Nov. 15, 2013).

98. Id.

99. Id.

100. Id.

101. Id.

102. (1681) 23 Eng. Rep. 286 (Ch.), 1 Vern. 32.

103. Id.

104. Id. at 287 (emphasis omitted).

105. See Cocking v. Pratt, (1749-50) 27 Eng. Rep. 1105, 1105 (Ch.), 1 Ves. sen. 400, 400 (granting "relief against agreement made under a misconception of right"); Bingham v. Bingham, (1748) 27 Eng. Rep. 934, 934 (Ch.), 1 Ves. sen. 126, 126-27 (holding chancery warranted to grant relief against a "plain mistake"); Lansdown v. Lansdown, (1730) 25 Eng. Rep. 441, 441 (Ch.), Mos. 364, 364-65 (granting relief against bonds and deeds obtained by mistake and misrepresentation); Broderick v. Broderick, (1713) 24 Eng. Rep. 369 (Ch.), 1 P. Wms. 239 (see the discussion of this case at Ricks, supra note 86, at 713-14). But see Mildmay v. Hungerford, (1691) 23 Eng. Rep. 757, 757 (Ch.), 2 Vern. 243, 243 (declining to grant relief for legal mistake from an already completed payment).

106. Henry Ballow, A Treatise of Equity 10 (Nutt \& Gosling 1737). 
undercutting of the consideration. ${ }^{107}$ Consider the words of the Virginia Supreme Court in Tucker v. Cocke $(1823)^{108}$ :

There are cases in which the mutual error of the parties, without default in either, may be a just ground for rescinding a contract. As, if the error be in a matter which is the cause of the contract, that is, in the substance of the thing contracted for, so that the purchaser cannot get what he bargained for.... In such cases, the contract ought to be vacated, even if it has been executed ....

\section{Unconscionability}

Imbalance in a bargain was supposed to be technically irrelevant to a breach of contract plaintiff's prima facie case, because the law did not judge the adequacy of consideration. ${ }^{110}$ But a hard bargain could form the factual basis for unconscionability, which did relieve a contracting party. Typically something in addition to an unequal bargain was required. ${ }^{111}$ My favorite hard bargain case is James $v$. Morgan (1663). ${ }^{112}$ A person promised "to pay for a horse a barley-corn a nail, doubling it every nail." "113 But there were thirty-two nails, and this amounted to 500 quarters of barley, or 4,000 bushels. ${ }^{114}$ Damages for failure to pay for the horse were alleged. ${ }^{115}$ On the general plea of non assumpsit, the court directed the jury to give 8 pounds in damages, which it did, a result that was confirmed on appeal. ${ }^{116}$ The case shows that the law courts in assumpsit cases were fully capable at a very early period of dealing with

107. See Ricks, supra note 86, at 717-23 (tracing the origin of mutual mistake from English equity reports through the development of the complete doctrine in the Virginia courts between 1798 and 1823); id. at 723-47 (showing the tie between mutual mistake and consideration).

108. 23 Va. (2 Rand.) 51, 1823 WL 1011 (1823).

109. Id. at 66 .

110. See, e.g., Sturlyn v. Albany, (1587) 78 Eng. Rep. 327, 328 (K.B.), Cro. Eliz. 67, 67 (“[F]or when a thing is to be done by the plaintiff, be it never so small, this is a sufficient consideration to ground an action ....").

111. See IBBETSOn, supra note 85, at 210-11; J.L. Barton, The Enforcement of Hard Bargains, 103 L.Q. R. 118, 118-21 (1987).

112. (1663) 83 Eng. Rep. 323, 1 Lev. 111.

113. Id. at 323 .

114. Id. For the measurement, see MASTER FitZHERBERT, THE BOOK OF HUSBANDRY 21 (Walter W. Skeat ed., Trubner \& Co. 1882) (1534), available at http://archive.org/stream/bookofhusbandry00fitzuoft/bookofhusbandry00fitzuoft_djvu.txt ("and if it ... be all beanes, it wyll haue foure London busshelles fullye, and that is half a quarter"); see also, e.g., OXFORD ENGLISH DICTIONARY quarter n.1, available at http://www.oed.com/view/Entry/156027?rskey=wRoo4Y\&result=1\&isAdvanced=false\#eid.

115. James, 83 Eng. Rep. at 323.

116. Id. 
hard bargains. ${ }^{117}$ In this case as in others I have read from the period there is almost surely some trickery involved. No one who has doubled an amount thirty-two times would agree to such a bargain. One can almost see the horse-seller turn and wink at his farrier while making the deal. We infer, as surely the court did, that the seller took advantage of the buyer's mathematical ignorance.

In the chancery, the deal might have been rescinded, ${ }^{118}$ or equitable relief denied. ${ }^{119}$ The word unconscionable stems ultimately from the name of the chancellor's jurisdiction. The chancellor was the keeper of the king's conscience. Pleas for relief from agreements on grounds of actions contrary to conscience occur from at least the 1400s. ${ }^{120}$ By the 1700 s, relief for a specific form of bad behavior in forming agreements was regular and well-established. In the chancery, it appears that something more than an unequal bargain was required to warrant relief. ${ }^{121}$ So Chancellor Hardwicke said in a case in 1741:

It is not sufficient to set aside an agreement in this court, to suggest weakness and indiscretion in one of the parties who has engaged in it; for, supposing it to be in fact a very hard and unconscionable bargain, if a person will enter into it with his eyes open, equity will not relieve him upon this footing only, unless he can shew fraud in the party contracting with him, or some undue means made use of to draw him into such an agreement ....

Even at the rhetoric's most generous turn, the chancellor wants to insist on something more than a mere hard bargain, but it's very difficult to tell what that might be, and the language the chancellor used allows all of that "something more" to be implied. So, for instance, Hardwicke

117. See also Thornborough v. Whitacre, 87 Eng. Rep. 1044, 1044, 6 Mod. 305, 305 (holding on facts similar to those of James v. Morgan, "Per Curiam, . . . : let them go to trial; and though this would amount to a vast quantity, yet the jury will consider of the folly of the defendant, and give but reasonable damages against him ....").

118. See, e.g., Berney v. Pitt, (1686) 23 Eng. Rep. 620, 621 (Ch.), 2 Vern. 14, 15-16 (discharging a prior decree based on the "unconscionableness of the bargain").

119. See, e.g., Barnardiston v. Lingood, (1740) 26 Eng. Rep. 484, 484-85 (Ch.), 2 Atk. 133, 134; Nott v. Hill, (1683, 1687) 23 Eng. Rep. 391, 392 (Ch.), 1 Vern. 167, 168.

120. See, e.g., Burton v. Gryville, (1420-22) 10 SELDEN Soc. 118, 119 (case no. 121) (Ch.) (petition "as law and conscience demand" that the Chancellor order the return of Alice Wodelocke, age 7, Burton's ward, who was being kept by Gryville and Robert Archer in order to induce Burton to pay 40 marks and also release Archer's debts to Burton); JACKSON, supra note 91, app. of cases (transcriptions of petitions from Chancery in the 1400s, many of which end in a plea for action for conscience's sake).

121. See Barton, supra note 111 , at $123-30$.

122. Willis v. Jernegan, (1741) 26 Eng. Rep. 555, 555 (Ch.), 2 Atk. 251, 251-52. 
said in a later case, "There are also hard unconscionable bargains, which have been construed fraudulent, and there are instances where even the common law hath relieved for this reason expressly." 123 The bargaining naughtiness was a construction from the hard bargain. Hardwicke claimed equity would engage in this construction more readily than would law: "[T]his court will relieve against presumptive fraud, so that equity goes further than the rule of law, for there fraud must be proved, and not presumed only." 124 So, where the court granted relief, "fraud has been constantly presumed, or inferred from circumstances, and conditions of parties; weakness and necessity on one side, and extortion and avarice on the other, and merely from the intrinsic unconscionableness of the bargain." 125 The chancellor assured from his actions that he would actually look in a real case for any bargaining disability or naughtiness. ${ }^{126}$ All this rhetoric, including its ambiguity, sounds remarkably like our unconscionability defense today. ${ }^{127}$

123. Earl of Chesterfield v. Janssen, (1750) 26 Eng. Rep. 191, 224 (Ch.), 1 Atk. 301, 351.

124. Id.

125. Id. at 225 .

126. See id. ("And yet I do admit more circumstances appear here in favour of the [creditor], than have concurred in the rest of the cases: Mr. Spencer was 30 years of age, there is no foundation to say he was a weak man, nor any charge in the bill of that kind, the bargain was unsought for by the defendant, and intirely [sic] proceeding from the borrower, who was of a broken constitution; the money too was borrowed for an honest purpose, to pay debts ....").

127. In fact, Lord Hardwicke's language was quoted in the United States as late as 1930. See Sullivan v. Murphy, 232 N.W. 267, 270 (Iowa 1930); Butler v. Haskell, 4 S.C. Eq. (4 Des. Eq.) 651, 684 (1817). Language much like his is abundant in unconscionability cases, however. See Lovey v. Regence BlueShield of Idaho, 72 P.3d 877, 881-82 (Idaho 2003) ("Courts do not possess the roving power to rewrite contracts in order to make them more equitable. Equity may intervene to change the terms of a contract if the unconscionable conduct is serious enough to justify the court's interference. 'While a court of equity will not relieve a party from a bargain merely because of hardship, yet he [or she] may claim the interposition of the court if an unconscionable advantage has been taken of his [or her] necessity or weakness.' It is not sufficient, however, that the contractual provisions appear unwise or their enforcement may seem harsh." (citations omitted)); see also, e.g., Day v. DB Capital Group, LLC, No. DKC 10-1658, 2011 WL 887554, at*15 (D. Md. Mar. 11, 2011) ("In Maryland and elsewhere the prevailing view is that both procedural and substantive unconscionability must be present for a court to invalidate a contract or clause under the doctrine of unconscionability. Procedural unconscionability focuses on the bargaining process that led to the formation of the contract and 'looks much like fraud or duress.' Substantive unconscionability 'involves those one-sided terms of a contract from which a party seeks relief."' (citations omitted)); Cowbell, LLC v. Borc Bldg. \& Leasing Corp., 328 S.W.3d 399, 405-06 (Mo. Ct. App. 2010) (“A contract is found unconscionable where it is so strongly, grossly, and manifestly unequal that someone with common sense would exclaim at the inequality of it. However, '[i]nequality in value between the subject matter and the price, standing alone, does not rise to the level of unconscionability which requires the refusal of specific performance.' Rather, we determine whether an agreement is unconscionable in view of the circumstances in which the contract was made. Inadequate consideration will not mandate the denial of specific performance "unless accompanied by other inequitable incidents or unless the disparity is so gross as to show fraud."” 
In short, the doctrine of unconscionability was well-developed before assent became part of the law. These defenses all began and developed as defenses against a bargain, not against mere assent.

\section{Defenses Against Consideration: Doctrine, Logic, AND POLICY}

It is no accident that these defenses arose when a prima facie case for promise enforcement depended primarily on consideration, and assent doctrines had not yet been formulated. The defenses all do more than undercut assent. In fact, the defenses are best understood as undercutting not assent but consideration. Assent is incomplete as a rationale for these defenses.

\section{A. What Consideration Is For}

Demonstrating how the defenses match consideration from the standpoint of policy and logic requires a discussion of the policies served by the consideration doctrine. The justification for our contract formation defenses is easier to see if we keep in mind why consideration was and is required. I find consideration so poorly defended today that the reasons for it are easy to miss, ${ }^{128}$ but the doctrine developed for reasons, and few of them are merely historical. Of course, in the beginning, the point of an extra element in an assumpsit action was to

\footnotetext{
(citations omitted)); Carey v. Lincoln Loan Co., 125 P.3d 814, 828 (Or. Ct. App. 2005) (“The primary focus, however, appears to be relatively clear: substantial disparity in bargaining power combined with terms that are unreasonably favorable to the party with the greater power may result in a contract or contractual provision being unconscionable. Unconscionability may involve deception, compulsion, or lack of genuine consent, although usually not to the extent that would justify rescission under the principles applicable to that remedy. The substantive fairness of the challenged terms is always an essential issue."); cf. PERILLO, supra note 8, § 9.40; FARNSWORTH, supra note $4, \S 4.28$.

128. Exceptions exist in which consideration is given more of its due. See Peter Benson, The Unity of Contract Law, in THE THEORY OF CONTRACT LAW 118 (Peter Benson ed., 2001); Edwin Butterfoss \& H. Allen Blair, Where is Emily Litella When You Need Her?: The Unsuccessful Effort to Craft a General Theory of Obligation of Promise for Benefit Received, 28 QUINNIPIAC L. REV. 385, 420-26 (2010); Melvin Aron Eisenberg, The World of Contract and the World of Gift, 85 CAL. L. REV. 821 (1997) (defending a quite limited argument for caution about "simple donative promises"); David Gamage \& Allon Kedem, Commodification and Contract Formation: Placing the Consideration Doctrine on Stronger Foundations, 73 U. CHI. L. REv. 1299 (2006); Daniel Markovits, Contract and Collaboration, 113 YALE L.J. 1417 (2004). I find all of these quite ethereal. My interest is in consideration as a functioning legal doctrine, not as an instantiation of grand social theory. Grand social theory is an interesting activity, but its abstractions are so... well ... abstract.
} 
distinguish the action from one sounding in covenant or debt, so that the forms of action did not overlap. ${ }^{129}$ This reason is now obsolete, but it became obsolete in part in 1605 or a decade or two thereafter, when nearly all the judges came around to the position in Slade's Case ${ }^{130}$ that some actions that could be brought in debt could also be brought in assumpsit. ${ }^{131}$ It became entirely obsolete in the 1800 s when the forms of action were abolished in most states. Judges kept the consideration doctrine, however, for the last four hundred years despite several opportunities to abandon it. ${ }^{132}$ The simplest explanation is that judges still want it.

Readers on this issue should remember, though, that consideration as a doctrine has been rationalized extremely slowly. Explanations for it were in their infancy in the late 1800s when Holmes first addressed it and attacked it, ${ }^{133}$ and the feeling for decades afterwards was that consideration might well become a formality and dissolve away like the seal. ${ }^{134}$ Only later did scholars begin to defend the doctrine, and then only half-heartedly. ${ }^{135}$ Only lately have its defenders begun to outnumber its detractors in print. ${ }^{136}$ Eventually, I believe explanations

129. See Ibbetson, supra note 13 , at $142-51$.

130. (1602) 76 Eng. Rep. 1072 (K.B.), 4 Co. Rep. 91a. The case arose in the King's Bench but was decided by agreement of judges from the Common Pleas and Exchequer, also.

131. See David Ibbetson, Sixteenth Century Contract Law: Slade's Case in Context, 4 O.J.L.S. 295 (1984).

132. For instance, judges could have abandoned it by following Pillans $v$. Van Mierop, (1765) 97 Eng. Rep. 1035 (K.B.), 3 Burr. 1663; or when the forms of action were abolished; or when the first Restatement of Contracts proposed to turn it into a formality; or when deciding whether to abandon the seal; or slowly by judicial decision. See Ricks, supra note 1, Part III.B.2. But they did not. See id.

133. Holmes, supra note 6, at 289-307.

134. See, e.g., Clarence D. Ashley, The Doctrine of Consideration, 26 HARV. L. REV. 429, 429 (1913) ("It is further true that consciously or not the law of consideration is being modified gradually, until the present technical requirement is likely to be entirely abolished."); Arthur Linton Corbin, Non-binding Promises as Consideration, 26 CoLUM. L. REv. 550, 556 (1926) ("[T]he time has come to abandon the requirement of a consideration...."); see also Kevin M. Teeven, The Advent of Recovery on Market Transactions in the Absence of a Bargain, 39 AM. Bus. L.J. 289, 292-335 (2002).

135. See, e.g., Lon Fuller, Consideration and Form, 41 CoLuM. L. Rev. 799, 799-800 (1941); see also, e.g., Edwin W. Patterson, An Apology for Consideration, 58 Colum. L. Rev. 929 (1958).

136. Compare LaW Revision CommitTeE, Report on the STAtute of Frauds and the DOCTRINE OF CONSIDERATION (Sixth Interim Report, Cmd. 5449, 1937) (law reform commission report recommending that the consideration doctrine be abolished in the United Kingdom), and James D. Gordon III, A Dialogue About the Doctrine of Consideration, 75 CORNELL L. REV. 986 (1990), and James D. Gordon III, Consideration and the Commercial-Gift Dichotomy, 44 VAND. L. REv. 283 (1991), and Ernest G. Lorenzen, Causa and Consideration in the Law of Contracts, 28 YALE L.J. 621, 643-46 (1919), and Roscoe Pound, Individual Interests of Substance-Promised Advantages, 59 HARV. L. ReV. 1, 38 (1946), and Malcolm P. Sharp, Pacta Sunt Servanda, 41 
will settle around a consensus, but belated recognition that the doctrine is not going away has delayed clear thinking about the issue.

The consideration doctrine makes sense, and makes most sense, when its operation in the law-its use - is kept firmly in mind. Only then is the consideration doctrine's necessity obvious.

The doctrine of consideration operates almost exclusively as a measure to judge the adequacy of the plaintiff's complaint. The plaintiff files a complaint that alleges the elements of a breach of contract claim. The judge in response must decide whether to require the defendant to answer, or, if the defendant does not appear, whether to receive proof from the plaintiff of a prima facie case and issue default judgment.

At this point in the contract litigation proceeding, if the parties' assent stood alone, without the element of consideration, then the law would have little reason to act on the plaintiff's case to require an answer or give default judgment. Perhaps some would argue that the law ought to trust everyone's assent, because people are entitled to their dignity under the law. But I suspect they do not seriously mean this in this context. Suppose a complaint is filed alleging that the defendant assented to pay $\$ 5,000$ to the plaintiff and has not paid. The complaint alleges that the plaintiff assented to this other assent, but of course the plaintiff assented to this promise in the plaintiff's interest. We can assume, because the lawsuit was thought necessary, that the defendant has not paid. Should a court without further inquiry grant such a complaint? I hope not. Put yourself in the position of a trial judge. The plaintiff alleges that the defendant assented to pay $\$ 5,000$ and has not. That is all you know. Should that be enough to form a prima facie case for an enforceable promise? ${ }^{137}$

I hope you answer not. A state's response to a legal complaint is

Colum. L. Rev. 783 (1941), and Mark B. Wessman, Retaining the Gatekeeper: Further Reflections on the Doctrine of Consideration, 29 LOY. L.A. L. REV. 713 (1996) [hereinafter Wessman, Retaining the Gatekeeper], and Mark B. Wessman, Should We Fire the Gatekeeper? An Examination of the Doctrine of Consideration, 48 U. MiAMI L. REV. 45 (1993) [hereinafter Wessman, Should We Fire the Gatekeeper?], and Lord Wright, Ought the Doctrine of Consideration to Be Abolished from the Common Law?, 49 HARV. L. REV. 1225 (1936), with Benson, supra note 128, and Howard Engelskirchen, Consideration as the Commitment to Relinquish Autonomy, 27 SETON HALL L. REV. 490 (1997), and Fuller, supra note 135, and Gamage \& Kedem, supra note 128, and Markovits, supra note 128, and Patterson, supra note 135, and Val D. Ricks, The Sophisticated Doctrine of Consideration, 9 GeO. MASON L. Rev. 99 (2000).

137. As Professor Corbin said it, "Should the Requirement of Consideration be Abandoned? Perhaps the question here put is substantially the same as, Should all promises be enforced. If it is the same, there is little use in putting it. By no system of law have all promises been enforced." ARTHUR LINTON CORBIN, CORBIN ON CONTRACTS: ONE VOLUME EDITION § 111 (1952). 
costly. The plaintiff is asking you to bring the machinery of the state to bear against a (normally) taxpaying, law-abiding citizen. Is the mere fact of assent enough for you to send the sheriff out? The mere assent of a party should not be sufficient to warrant the state's moving to action against them, both because the state's machinery ought to require more in the way of publicly plausible reasonableness and also because the state's machinery ought not to be used for solely private purposes. Leaving the law of contracts solely to assent would violate both of these principles.

Please keep in mind also that a legal complaint is not filed until the parties cannot solve the dispute on their own. We can generally assume that the plaintiff has already asked the defendant to perform, and that the defendant has declined while knowing that the plaintiff will be marching off to court to get a judge to order payment. Some defendants delay performance just to put the plaintiff to the cost of suit, but most do not. Presumably there is some reason why the defendant has not paid. If you conclude that the promise is binding on evidence of the promise alone, have you not assumed already that the defendant is wrong, and thus prejudged the case? Should you not know something more about the reasonableness or quality of the assent before you order it answered or grant damages for its breach?

Consideration when added to the fact of promise means that the promise has been proved reasonable enough to enforce to the extent of requiring an answer or a default judgment. It also proves enough of a public benefit to call the state's machinery into action. Of course, that seldom ends the inquiry. In the face of actual evidence of duress, misrepresentation, mistake, unconscionability, the non-occurrence of a condition, or the inappropriateness of a remedy, the court will reconsider that prima facie judgment. But at the stage of the inquiry in which it operates, the consideration doctrine requires enough proof that court action is worth the public's time and the violence that a court proceeding and judgment might work against a private citizen.

Most of this was spelled out in the sixteenth century when litigation in the central courts, in which the consideration doctrine operated, was limited to an examination of the prima facie case and to appeals after trial. At the time, the doctrine of consideration was justified on several grounds. For instance, consideration for a promise helped ensure that the promise was reasonable. Christopher St. German stated in describing promises that were unenforceable under the common law of contract in 
1530, "These be called naked promises, because there is nothing assigned why they should be made."138 Reason clothed a promise. Common lawyers adopted the nudity metaphor soon after the consideration doctrine formed, ${ }^{139}$ letting consideration fill the justificatory slot St. German had named.

As the doctrine was maturing in the 1560s, Fleetwood and Wray (later Wray, C.J. of the King's Bench) argued that the common law "requires that there should be a new cause, whereof the country [jurors] may have intelligence or knowledge for the trial of it, if need be, so that it is necessary for the public-weal." ${ }^{140}$ The acts which result in liability ought to be notorious, they argued, like livery of seisin. ${ }^{141}$ In other words, at a minimum the deal had to be public in some way. We might take this in two ways, depending on what it is Fleetwood and Wray wanted the public to know-the cause of the promise or action, on the one hand, or merely the fact of the promise itself (that the promise occurred).

If they meant that the cause of the promise or action must be public, then consideration was for this reason (also) a kind of reasonableness standard: It ensured that the cause of the promise or the lawsuit be publicly understandable, plausible to the public. The courts actually followed such a standard in several cases. ${ }^{142}$ The doctrine conceived this way is a check on reasonableness as St. German advocated, but one less stringent than a finding of actual reasonableness. A benefit to the promisor or a detriment to the promisee provided just such a public reason, either for a promise or for liability, and the requirement of mutual inducement tied the promise and reason together. "For our Law requireth in all contractes a mutuall consideration," Fulbecke explained in 1602, "and one part of the contract challengeth and begetteth the other." 143 And that requirement avoids liability arising from things

138. Christopher St. German, Doctor And Student (1530), reprinted in 91 Selden Soc. 1, 228, 229 (T.F.T. Plucknett \& J.L. Barton eds., 1974), as reprinted in BAKER \& MILSOM, supra note 63 , at 484 .

139. E.g., Goodwin v. Willoughby, (1626) 79 Eng. Rep. 1273, 1273 (K.B.), Pop. 177, 177; Lampleigh v. Brathwait, (1615) 80 Eng. Rep. 255, 255 (C.P.), Hob. 105, 106; Sydenham \& Worlington's Case, (1585) 78 Eng. Rep. 20, 20 (C.P.), Godb. 31, 31.

140. Sharington v. Strotton, (1565) 75 Eng. Rep. 454, 460 (K.B.), 1 Pl. Com. 298, 302.

141. Id.

142. E.g., Riches v. Bridges, (1602) 78 Eng. Rep. 1108, 1108 (K.B. \& Ex. Ch.), Cro. Eliz. 883, 884, 80 Eng. Rep. 4, Yel. 4 (from Croke: "it shall be intended that he had some benefit thereby"); Reynolds v. Pinhowe, (1594) 78 Eng. Rep. 669, 669 (K.B.), Cro. Eliz. 429, 429 (holding consideration enough on a benefit that "may be there").

143. William Fulbecke, The Second Part of the Parallele, or Conference of the 
people do "of their owne head," he explains. ${ }^{144}$

Alternately, if Fleetwood and Wray were talking about the cause being evidence of the promise itself, or at least an intent to be bound, then consideration serves for this purpose as a formality that proves a promise or that intent. This purpose is roughly equivalent to what Fuller later called consideration's "evidentiary function."145 As an interpretation of Fleetwood and Wray, ${ }^{146}$ I think this doubtful, but Fuller is quite right that consideration as a formality would provide additional evidence that a promise was made, and he has Mansfield, C.J., in Pillans v. Van Mierop ${ }^{147}$ to back him up, for what that is worth.

Fuller also posited something he called "channeling function." 148 Consideration, he claimed, "furnishes a simple and external test of enforceability." "149 This also, in fact, may have been what Fleetwood and Wray were arguing for in the $1560 \mathrm{~s},{ }^{150}$ and consideration certainly fills this function. But it does not do it very well. It is not simple. The general rule requiring a bargained-for promise or performance has exceptions and corollaries that must be learned if the lawyer is to understand and apply the doctrine correctly. Certainly there is justification for the length as well as the existence of Chapter 4 of the Restatement (Second) of Contracts. And we should not expect juries to understand consideration well. Law students barely grasp it, even when it is taught to them at length, and judges, too, make contradictory statements regarding it. ${ }^{151}$ Moreover, a seal is so much better at this function. A plain signed writing would have been so much better, or some other public ceremony. This makes us doubt Fuller's argument.

In the same case in which Fleetwood and Wray argued, Plowden for

Ciuill Law, the Canon Law, and the Common Law of this Realme of England 18b (London, Thomas Wight ed., 1602).

144. Id. at 19. Fulbecke's first example is Hunt v. Bate, (1568) 73 Eng. Rep. 605 (C.P.), 3 Dy. 272a, in which liability for the defendant's promise is denied on the ground that the promisee had incurred the detriment "of his own head" rather than because he was induced by the promise. Id. at 606. A public reason was wanting. The alleged consideration in Hunt also occurred before the promise was made, so the case is also rationalized as a past consideration case, time analysis functioning as a surrogate for causation. $I d$.

145. Fuller, supra note 135, at 799-800.

146. Fuller cited Sharington v. Strotton. See supra note 135, at 799 n.2.

147. (1765) 97 Eng. Rep. 1035, 1038 (K.B.), 3 Burr. 1663, 1669 (Mansfield, J.) ("I take it, that the ancient notion about the want of consideration was for the sake of evidence only ....").

148. Fuller, supra note 135 , at 801.

149. Id.

150. See supra text accompanying notes $140-44$.

151. See, e.g., Ricks, supra note 1, Part III.B.2.e (discussing the peppercorn jurisprudence). 
the opposing party proposed another rationale. The purpose of a sealed document, he argued, is "because words are oftentimes spoken by men unadvisedly and without deliberation." 152 So the law enforces sealed documents "without examining upon what cause or consideration they were made." $" 153$ The implicit premise in the distinction is that an examination of consideration is meant to ensure the reasonableness of the deal-at least that the deal's wisdom is plausible. But Plowden appeared willing to equate consideration with the formality of a seal. This is the origin of what Fuller later called consideration's "cautionary function." 154

But there are other substantive justifications for the doctrine. For instance, requiring mutual inducement means that the law favors beneficial transactions. ${ }^{155}$ Neither party would be induced by a transaction unless each saw it as in her best interests, with benefits outweighing costs. That's what inducement means. A transaction in which both parties benefit is economically better for them, and I mean that in the broad sense that it will increase their utility. It is also economically better for society, at least in theory, as it moves goods or services to those who value them more highly than those who possess them before the transaction. So everyone, assuming these kinds of transactions are encouraged equally for all, is or can be more satisfied than before. Enforcing a transaction in which both parties benefit is also morally superior, or at least morally less problematic, than enforcing a transaction in which one party benefits and the other does not or, worse, merely suffers a detriment. Of course, consideration does not require that both parties actually benefit, but the mutual inducement requirement means that, ex ante, both parties must see plausible benefits from the transaction that could outweigh the costs of entering into it.

The consideration doctrine also ensures that reason for a lawsuit exists, and points to a proper remedial measure. When benefit to the promisor exists as consideration, this reason alone, independent of other reasons for contract enforcement, suggests that a promisor should be bound. After receiving a bargained-for benefit, the promisor would be enriched unjustly unless made to perform or pay. As between giving up

152. Sharington v. Strotton, (1565) 75 Eng. Rep. 454, 470 (K.B.), 1 Pl. Com. 298, 308.

153. Id.

154. Fuller, supra note 135, at 800.

155. Something like this is asserted at Charles J. Geotz \& Robert E. Scott, Enforcing Promises: An Examination of the Basis of Contract, 89 YALE L.J. 1261, 1293-97 \& passim (1980); see also EPSTEIN, supra note 8, at 71-82. 
the benefit and performing the promise given in exchange for the benefit (or paying damages for its breach), the remedy focused on the promise would generally hew more closely to the parties' understanding of the transaction, and should normally govern. When it does, it reflects the strength of the exchange concept.

When benefit to the promisor does not exist but the promise has induced some performance which itself induced the promise, then the promisee should be reimbursed for the costs of that performance, both for reliance and lost opportunity. The exchange of the promise for the performance makes the performance worthy of reimbursement. As for remedy, the value of the bargained-for promise is the best guide to what the parties thought was the value of that performance, and, as with benefit, is for that reason a preferable measure of the harm done to the promisee over the actual costs of performance, or the costs of lost opportunity (often difficult to prove), though these together might work as an alternative. ${ }^{156}$ In fact, the value of the bargained-for promise is the remedy most closely aligned with the market for that deal at the time the deal occurred, which is why giving an expectation measure better assures that incentives to rely on bargains continue to exist.

Similar rationales exist for enforcing mere mutual promises. If one of the two exchanged promises is performed before breach of the other, then the benefit or detriment, or both, resulting from performance provides sufficient ground alone for enforcement of the promise. But if breach occurs after a trade of mutual promises but before any performance has occurred, the fact of exchange alone supports enforcement. Much ink has been spilled on whether executory mutual promises should be enforceable, ${ }^{157}$ but for the most part, this situation is not different from the others. The same trade of promise and consideration occurred here as occurred in other cases, so the rationality of the promise and the public benefits from its enforcement are sufficiently evidenced by proof of the bargain. The so-called cautionary function is equally served. We have no less reason here to believe that the parties have, from an ex ante perspective, chosen a mutually beneficial outcome, and in a morally superior way. The bargain also

156. FARNSWORTH, supra note $4, \S 2.3$.

157. See, e.g., FRIED, supra note 4, at 7-27 (making an argument from autonomy); MiCHAEL J. TREBilcock, ThE Limits OF FreEdom of CONTRACT 164-68 (1993) (claiming enforcement is based on efficiency); Engelskirchen, supra note 136 (also autonomy); Val D. Ricks, In Defense of Mutuality of Obligation: Why "Both Should Be Bound, or Neither", 78 NEB. L. REV. 491, 530 n.184 (1999) (an argument from custom). 
gives guidance on what would constitute a proper remedy. The only thing missing is direct harm, but only the fortuity of early breach has stopped it from occurring.

From the judge's standpoint, the lack of direct harm is not a serious objection. The law presumes that both promises are generally enforceable as part of the bargain, and this resolves the issue for the most part. ${ }^{158}$ If a plaintiff is able to recover from the breaching defendant, then the defendant should be able to recover from the plaintiff (or at least the lack of the plaintiff's performance should mitigate damages). If one promise is enforceable, then, at least ex ante, all else being equal, the other should be; the law's commitment to treat the parties equally requires it. ${ }^{159}$ Once the law decides to enforce one promise, the law could hardly refuse to enforce the other and remain fair. The bargain ties the two parties' promises together in such a way that enforcing one requires that the other be treated equally, so once we make one bargained-for promise enforceable, the other should be as well. ${ }^{160}$ This is the policy origin of the often-maligned but (when understood) salutary mutuality of obligation rule. ${ }^{161}$ After all, the parties' bargain implies that they themselves thought the trade worth doing. Making both promises enforceable allows the law to catch the public benefits of bargaining without offending anyone's interests. ${ }^{162}$

158. Ricks, supra note 157 \& passim.

159. Of course, this is true only in a general sense. One potential exception occurs when the plaintiff's promise is subject to some defense, such as the statute of frauds or one of the formation defenses. The plaintiff's promise then might never be legally enforceable. Courts have often enforced the defendant's promise nonetheless. Id. at 511-15, 526, nn.105-20. The defendant should not, after all, be able to take advantage of the plaintiff's defense. Another exception occurs when the contract calls for only one performance, as in certain legal gambling contracts (a bet on a race, for example). Consideration in a gambling contract is the mutual promise, but after the event bet on occurs, only one party need perform; the other merely collects the money. Where legal, this is an exception to the general policy. Id. at 506-07, n.85.

160. Id. at 516-41.

161. Id. at $517-30$.

162. Historically, the law developed so that enforcement of one of two executory mutual promises happens very rarely. Early on, the two promises were each enforceable independently based on the bargain, regardless of whether either of the parties had performed. See, e.g., Nicholas v. Raynbred, (1615) 145 Eng. Rep. 215, 216 (Ex. Ch.), Jenk. 296, 296 (also reported at 80 Eng. Rep. 238, Hob. 88); Gower v. Capper, (1596) 78 Eng. Rep. 790, 790 (K.B.), Cro. Eliz. 543, 543 (also reported at 74 Eng. Rep. 1029, Noy 61); SiMPSON, supra note 15, at 461-65. That changed with Kingston v. Preston, (K.B. 1773), reported within Jones v. Barkley, (1781) 99 Eng. Rep. 434, $437-$ 38 (K.B.), when the default rule shifted to finding one promise a constructive condition of the other, meaning that generally a promisee who has not yet performed must tender before alleging breach. See 2 FARNSWORTH, supra note $4, \S 8.9$. The consequence is that generally one of two mutual promisors performs or at least tenders before suit. 
A similar answer to the objection (that, in a case of mutually executory promises, no direct harm exists) is that direct harm does exist; the objection is simply incorrect. Breach of a bargained-for promise is (or should be) itself a compensable harm. This conclusion is premised on the notion that each side of a bargain is related transitively to the other side. This premise is derived from the parties' trading them for each other; the parties (at least) think of them as equivalent, or at least not less than each other. That is a logical consequence of a requirement of mutual inducement. Thus, a bargained-for performance (performed) warrants enforcement of a bargained-for promise.

If a bargained-for performance (performed) warrants enforcement of a bargained-for promise, then a bargained-for promise also warrants a bargained-for performance. That is why we do justice to the nonbreaching party who has performed when we give them a remedy based on their expectation that the other party's promise would be performed. If the bargained-for promise did not warrant their performance, then we would be over- or under-compensating with an expectation remedy. The performance justifies enforcing the promise, but enforcing the promise justifes, ex post, the bargained-for performance. If that is so, then a bargained-for promise certainly justifies, both ex ante and ex post, a bargained-for promise given in return.

In other words, if the law enforces bargains in which one party has performed, it must enforce both sides. And if a bargained-for promise also warrants a bargained-for performance, then the bargained-for promise of the plaintiff, even though the plaintiff has not yet performed, also warrants a similar remedy.

Give the exchange its full due. The parties have exchanged promises. If we credit the judgment that goes into inducement-if the parties really are minimally reasonable - and that justifies their promise such that the performance warrants enforcement of the promise on the other side of the bargain, then it ought to work for mutual promises, too. Put still another way, if a promise can be one half of an enforceable bargain, and in that space considered equal to the other half of the bargain in the eyes of the parties and derivatively under the law, then promises can also serve as both halves of an enforceable bargain.

One point gleaned from this examination of benefit, detriment, and mutual promise can be stated another way. The requirement of an exchange frees the courts from examining the quality of assent, at least without further reason to do so. If the parties have exchanged, then prima facie what they are trading is roughly equivalent, at least in the parties' eyes, and they are the people whose interests are most relevant to 
both the transaction and the litigation. They are also the people who know the deal best. The fact of their exchange thus suggests that the deal is good. Alternately, we can conclude that the parties themselves have conceded by exchanging that the deal is good for each of them, and that the promise is roughly equal in value in their eyes to the consideration, which is the price extracted for it.

There is a final set of interests served by the consideration doctrine that differs from the others. Before discussing it, I wish to remind readers that one can talk about contract law's substance without mentioning assent at all. Contract law, with consideration playing its full conceptual role, is not based on mere assent but on promise. In the hypothetical above, I was trying to focus on assent for the benefit of those who do, so I wrote the silly phrase "assented to pay," but no one talks this way normally, and I am not sure the phrase has a meaning unless it means a promise to pay. A promise is required, though evidence of it can include any variety of conduct or assent to such conduct so long as a promise is expressed or implied. The assent doctrine forgets this or at least makes no mention of it, and so we appear to require theorists to remind us that some kind of promise is necessary (at least they keep reminding us ${ }^{163}$ ). The consideration doctrine, on the other hand, requires consideration for a promise, so the focus is where it should be, on the promise that was breached.

Once we remember that a promise is required, there is another reason for keeping the consideration doctrine, and that is that lack of consideration is in some cases a worthy ground for non-enforcement. Given that consideration builds the prima facie case our law should require, the lack of it should sometimes be a defense. I believe there is wide agreement on many case lines (though not all) that a correct result is reached when courts decline to enforce a promise because consideration is lacking. Our common law of contracts handles these as consideration cases and not under any other doctrine, and if we were to do away with the consideration doctrine we would have to find another place for them.

The relatively recent $\operatorname{Kim} v$. Son ${ }^{164}$ is a good example. Son was the

163. E.g., FRIED, supra note 4, at 1; Jody S. Kraus, The Correspondence of Contract and Promise, 109 Colum. L. Rev. 1603 (2009); Seana Valentine Shiffrin, The Divergence of Contract and Promise, 120 Harv. L. Rev. 708 (2007). Lest we be confused between the morality of promising and what happens in a contract, Professor Pratt denotes it an "undertaking." Michael G. Pratt, Contract: Not Promise, 35 FLA. ST. U. L. REV. 801 (2008).

164. Kim v. Son, No. G039818, 2009 WL 597232 (Cal. Ct. App. Mar. 9, 2009). 
majority shareholder of a couple of corporations. ${ }^{165}$ After months of investigation, Kim loaned money to the corporations. ${ }^{166}$ The corporations defaulted, and Kim lost his investment. ${ }^{167}$ Son and Kim later met in a restaurant, where a drunken Son, full of remorse for Kim's loss, asked a waiter for a pin. ${ }^{168}$ Son pricked his finger and wrote out in blood, "I will repay you to the best of my ability." 169 There was no question that Son had made a serious promise to pay Kim back. The promise was not unclear: the amount owed Kim was a liquidated sum. ${ }^{170}$ Clearly, Son assented.

But Son was not the borrower; and the court refused to enforce the promise $^{171}$ —quite rightly, I believe. Son did not owe this money, and the law does not enforce such promises merely because they were said, even when said seriously and assented to by the promisee. ${ }^{172}$ Nor does morality require it; Kim invested in the corporations, and giving Kim also the benefit of a post hoc guarantee would give him more than he bargained for. Nor, because the promise occurred after the loan and default, would welfare be served by enforcing Son's promise. In fact, given that Son had been drinking and was feeling guilt and the obligations of friendship very strongly that day, ${ }^{173}$ we should suspect that his promise would serve no one's welfare, including his own. Nor is freedom curtailed by the law's refusing to enforce the promise: If Son really wants to pay, he still can. He just cannot be made to abide by his promise to pay, and that is because contract is actually grounded in consideration-some reasonableness or at least plausible wisdom for the promise, not just in assent.

I suspect most of us would agree that Son should not be made to pay, but it is not clear that any argument other than lack of consideration would have saved him, which is why the case centered around that doctrine. No matter whether one agrees or disagrees with other corollaries of the consideration rule-the proscription against preexisting contractual or non-contractual legal duties serving as

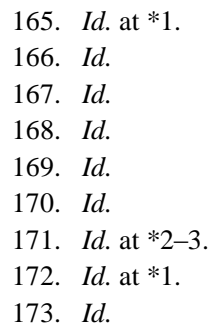


consideration, ${ }^{174}$ the need for a settlement to be based on more than an obviously empty legal claim, the illusory promise rule, the past consideration rule, etc. - if one agrees with any case decided under any of these doctrines, then one has to admit a place for the consideration requirement or make up another doctrine to replace it. I doubt any other doctrine could handle these situations as efficiently as consideration does, so unless the consideration doctrine is generating results that are not only wrong but very costly, and the cost-benefit calculation would change significantly if the problems were handled by some other rule, I propose we stick with the consideration doctrine for these cases.

To sum up, on the issue of what the consideration doctrine does and is for - the old cases may teach us. In Gower v. Capper (1596), ${ }^{175}$ a debtor promised that, if his creditor would show him the bill proving the debt, he would obtain sureties to pay the debt. ${ }^{176} \mathrm{He}$ did not obtain sufficient sureties, and when he was sued, he complained there was no consideration. ${ }^{177}$ The Queen's Bench responded, "[A] promise against a promise is a sufficient ground for an action." 178

"Ground for an action"- that's key language, it seems to me-not "ground for a contract" or "ground for a promise," but ground for an action. On that issue, the common lawyers seem to have understood quite correctly that consideration grounded an action. Assent alone does not. A defense to an action should take away the ground for the action. Because one cannot have consideration without assent, removing assent removes consideration, but there is no reason for the defenses to aim only at the smaller target. One can ruin a cake by leaving out other

174. This rule has been modified, of course, either by a judicial finding of a substitute agreement or by fiat. See, e.g., Watkins \& Son, Inc. v. Carrig, 21 A.2d 591, 594 (N.H. 1941); Schwartzreich v. Bauman-Basch, Inc., 131 N.E. 887, 889-90 (N.Y. 1921). And the Restatement has recommended a change. See Restatement (SECOND) OF CONTRACTs § 89 (1981); see also Angel v. Murray, 322 A.2d 630, 636 (R.I. 1974) (using § 89). And the UCC has jumped in. U.C.C. § 2-209(1). These variations mostly prove my point, actually. When courts want to enforce, they do, and the doctrine of consideration does not stand in their way. But when courts do enforce without an exchange, the doctrine they adopt ensures that they have before them more than the bare assent of the parties. The reasonableness requirement of Carrig, the substitute contract requirement of Schwartzreich, the elements of $\S 89$, and the good faith requirement of the UCC all put before the court the information necessary to do what the consideration requirement requires: rule on the plausible reasonableness of the promise or a remedy based on it. Only the UCC makes the modification presumptively enforceable, putting the burden on the promisor to show why it was not. Perhaps in the commercial setting the difference is justifiable.

175. (1596) 78 Eng. Rep. 790 (K.B.), Cro. Eliz. 543.

176. Id. at 790 .

177. Id.

178. Id. 
ingredients besides flour. The ground for an action for breach of contract is larger than assent. It can be attacked by means other than attack on assent. That is what our contract formation defenses do, as the next Part II.B shows.

(Note: I have said nothing about donative promises, but they are largely beside the point. Consideration is a doctrine that includes, not excludes: It functions to provide reasons for enforcement, not nonenforcement (even promises without consideration are enforced if an independent ground for enforcement exists). ${ }^{179}$ The doctrine itself does not include a distinction between donative and non-donative promises. If donative promises should be enforced, it is for reasons other than exchange. In fact, at common law donative promises that generated reasonable action in reliance were enforceable under the doctrine of consideration! $!^{180}$ And courts could have found other donative promises

179. But see Wessman, Retaining the Gatekeeper, supra note 136; Wessman, Should We Fire the Gatekeeper?, supra note 136. Wessman concludes that the consideration doctrine is responsible for the non-enforcement of broad classes of promises that should be enforced. See Wessman, Should We Fire the Gatekeeper?, at 102-14. This conclusion depends in part on the idea that consideration is the only way to enforce a promise, but it is not. Not only do other means of enforcement exist within contract law, see, for example RESTATEMENT (SECOND) OF CONTRACTS §§ 82-94 (1981), but numerous other doctrines assist courts in reaching a just result when necessary, including, for example, unjust enrichment, agency law, and tort doctrines of fiduciary duties and assumption of a duty. Second, Wessman's conclusion depends on the idea that judges are forced by doctrine to exclude. I just do not see judicial ingenuity as so lifeless and judges as so powerless, at least not regarding things they care about. I believe judges do not see the benefits of expanding what counts as prima facie enforceable as worth the costs.

180. See, e.g., Teeven, supra note 134, at 292-334; William R. Casto \& Val D. Ricks, "Dear Sister Antillico ...": The Story of Kirksey v. Kirksey, 94 GEO. L.J. 321, 366-70 (2006); Ricks, supra note 136, at 112-18 (showing this line of cases was based on a fiction but was a clearly established line); see also Somers v. Miner, 9 Conn. 458, 466, 1833 WL 54 (1833); Trs. of Amherst Acad. v. Cowls, 23 Mass. (6 Pick.) 427, 431-39 (1828); Trs. of Farmington Acad. v. Allen, 14 Mass. 172, 175-76, 1817 WL 1876 (1817); Univ. of Vt. v. Buell, 2 Vt. 48, 54-56, 1829 WL 1068 (1829); Keyme v. Goulston, (1664) 83 Eng. Rep. 338, 338 (K.B.), 1 Lev. 140, 141; Storer's Case, (perhaps 1615) 73 Eng. Rep. 605, 607, 3 Dy. 272a, 272b n.32. The following passage from Doctor and Student (1530) is telling:

Yf he to whome the promyse ys made: haue a charge by reason of the promyse whyche he hathe also perfourmed: than in that case he shall haue an accyon for that thyng that was promysed thoughe he that made the promyse haue no worldely profyte by yt. As yf a man saye to an other (heele suche a poore man of hys dyssease/ or mke suche an hyghewaye/ and I shall gyue the thus moche/ and yf he do yt I thynke an accyon lyeth at the comon lawe. And more ouer though the thynge that he shall doo be all spyrytuall: Yet yf he perfourme yt I thynke an accyon lyeth at the comon lawe.

Christopher St. German, Doctor AND Student (1530), reprinted in 91 SELden Soc. 1, 230-31 (T.F.T. Plucknett \& J.L. Barton eds., 1974). Teeven makes the most complete argument I have found. We differ in his conclusion that "detrimental reliance as an independent ground for contract relief on informal promises was lost at law." Teeven, supra note 134, at 313 . I see no reason for that assertion. There were never many of these cases, and they did not break new ground. There was no explicit rejection of this line of cases. Atiyah, for one, notes evidence that lawyers still held 
enforceable without action in reliance, had they wanted to. For example, promises associated with marriage were held enforceable as with consideration. ${ }^{181}$ These were undoubtedly often donative, the father wanting to benefit the daughter. ${ }^{182}$ Recovery in these cases was often rationalized as given on consideration of affection. ${ }^{183}$ The gift was a kind of benefit to the father, who owed a natural duty of affection to the daughter. But if the promisor was not a parent of the bride, this rationale did not work. ${ }^{184}$ Enforcement in these cases could be rationalized on the ground that the promise was made before marriage and induced the marriage. ${ }^{185}$ But this rationale depended on one imagining that the newlyweds married for money, ${ }^{186}$ and on seeing the marriage as a detriment (or at least a costly action) (Coke expressed such a jaded view $^{187}$ ). Moreover, this use of consideration is no different than

by it. P.S. AtiYah, The Rise And Fall of Freedom of Contract 184-89 (1979). That lawyers in the United States continued this line without much ado, and did so well before the rationalization of consideration around bargain that Teeven discusses, suggests that Atiyah is correct to say that this kind of idea in the law "never disappeared," although the idea's breadth and full meaning were uncertain at the time (and Atiyah may or may not have described it accurately). Id. at 186.

181. E.g., Berisford v. Woodruff, (1616) 79 Eng. Rep. 345, 345, Cro. Jac. 404, 404; Applethwait v. Nertleys, (1587-88) 74 Eng. Rep. 727, 727, 4 Leo. 56, 57.

182. E.g., Crouch v. Givers, (1593) 78 Eng. Rep. 558, 558, Cro. Eliz. 307, 307. In Crouch, Mr. Givers promised Crouch "unum cubiculum," which Givers's counsel argued meant the furniture of a chamber. Id. Perhaps Crouch himself would have been happy with a money judgment instead, but the promise probably was of furniture from the bride's father's house, and the promise was a gift to the daughter.

183. See Marsh v. Rainsford, 74 Eng. Rep. 400, 401 (K.B.), 2 Leo. 111, 112 (Wray, J.) (“[H]ere the natural affection of the father to his daughter, is sufficient matter of consideration."); Marsh v. Kavenford, 78 Eng. Rep. 319, 320 (K.B.), Cro. Eliz. 59, 59 (Popham, J.) ("For the father's natural affection doth continue, and her advancement is sufficient cause of the promise."); Barker v. Halifax, (1600) 78 Eng. Rep. 974, 974 (C.P.), Cro. Eliz. 741, 741 (Walmsley, J.) (“[A]n assumpsit in consideration that you had married my daughter, to give unto you 401. was good; for the affection and consideration always continues.").

184. In Browne v. Garborough, (1587) 78 Eng. Rep. 324, 324 (K.B.), Cro. Eliz. 63, 64, 75 Eng. Rep. 1018, 1018, Gould. 94, 94, the promisor was a cousin of the groom, and the promise was made to the bride. The cousin had no reason to get involved except affection, and the judges referred to him as a "stranger" to the parties. Id. See also Bradley v. Toder, (1609) 79 Eng. Rep. 198, 198, Cro. Jac. 228, 80 Eng. Rep. 112, 112, Yel. 168, 168 (another cousin promisor called a "stranger" to the marriage).

185. Browne, 78 Eng. Rep. at 324 (Gawdy \& Schute, J.J.).

186. Cardozo in De Cicco v. Schweizer, 117 N.E. 807 (N.Y. 1917), wrestled with the inducement issue arising when a promise is alleged to be given on consideration of marriage. Rather than hold the parties married for money, Cardozo inferred inducement because "the natural consequence of the defendant's promise was to induce." $I d$. at 809.

187. Freeman v. Freeman, (1614) 81 Eng. Rep. 327, 327 (K.B.), 1 Rolle. 61, 61, 80 Eng. Rep. 1113, 1113-14, 2 Bulst. 269, 269-70; see also Ramsden v. Appleyard, (1720) 22 Eng. Rep. 333, 333, 2 Eq. Ca. Abr. 390, 391 ("[S]uch a Consideration is good at Law; for tho' no Profit accrues to the Promiser, yet the other Party, without this Promise, would be liable to a Loss or Damage, and that is a sufficient Consideration to support an Assumpsit at Common Law."). 
occurred with respect to other kinds of donative promise enforceable when the promisee takes the actions that the promise was intended to induce. Later, when litigants applied in Chancery for performance of marriage settlements, the Chancellor enforced them on consideration of marriage, and decided who could benefit from them by asking whether the person had suffered a detriment or was related by blood to anyone who had. ${ }^{188}$ Certainly something more was happening here than what later became known as promissory estoppel, and this was all done in the name of consideration.

The fact is, when judges wanted to enforce donative promises, they did, and they used the doctrine of consideration as the means. We have now cut off that line of cases from the consideration doctrine and narrowed consideration to exchange, ${ }^{189}$ but it hardly makes sense to cut off a line of consideration cases enforcing donative promises and then complain that the consideration doctrine does not enforce donative promises!

Moreover, caution should be exercised here. The argument is often phrased not as involving "donative" but "gratuitous" promises. One meaning of gratuitous is "being without apparent reason, cause, or justification."190 The law should not enforce such promises, and the consideration doctrine, which tries to ensure that there is some plausible reason for the promise or for an action on the promise before imposing state power to enforce, provides no support for enforcing them, nor should it. At any rate, now we handle donative promises under doctrines other than consideration, but that is because we have forgotten the reasons for the consideration doctrine and artificially narrowed its potential reach.)

\section{B. How the Defenses Undercut Consideration}

Duress, misrepresentation, mistake, and unconscionability all

188. See Sutton v. Chetwynd, (1817) 36 Eng. Rep. 96, 97 (Ch.), 3 Mer. 249, 253; Stephens v. Trueman, (1747-48) 27 Eng. Rep. 899, 900 (Ch.), 1 Ves. sen. 73, 74; Osgood v. Stroud, (1724) 88 Eng. Rep. 839, 840 (Ch.), 10 Mod. 533, 534-35.

189. I credit Holmes and Williston for cutting off this line of cases, primarily by explicitly reducing consideration to mere bargain. See, e.g., CoRBIN, supra note 137, §§ 110-27, 127 ("As is insisted herein, in many places, there are many promises that are enforced at law, even though there is nothing that is bargained for or given in exchange. In all such cases, there is some factor that is practically always called the 'consideration'; and it constitutes a reason for enforcement by the court."); Ricks, supra note 136, at 117-18.

190. Gratuitous, DICTIONARY.COM, http://dictionary.reference.com/browse/gratuitous (last visited Nov. 27, 2013). 
undercut these quite substantive reasons for the consideration doctrine as well as the formal requirements of consideration itself. Incidentally, undercutting consideration often also undercuts assent. Since mutual inducement is a broader concept than mere assent and presumes mutual assent has occurred, anything that erases mutual assent also erases the broader mutual inducement. But the defense doctrines do much more than erase mutual assent. Why should that be, if only assent is at issue? That they do more shows that assent is not their target. For ease of discussion, I begin analysis of each defense with doctrinal language from the Restatement (Second) of Contracts. ${ }^{191}$

\section{Duress}

Duress occurs when "assent is induced by an improper threat by the other party that leaves the victim no reasonable alternative."192 The Restatement uses the language of assent, but the meat of the duress charge is that inducement comes not from the consideration but from the threat. If one was not induced by the consideration, then one is not responsible for the benefits received from the other's performance, nor for the other party's detriment, and one has not admitted that the promises are formally equal and publicly beneficial so as to justify an action upon them. The duress doctrine also requires that the victim be left "no reasonable alternative." The result is that all plausible public reason for the deal is gone. There is no public justification for using the machinery of the state to enforce the promise, then.

Notice, incidentally, that in the Restatement test in particular a manifestation of assent still occurs notwithstanding duress. Actual assent is not required for an enforceable promise, ${ }^{193}$ so lack of real, subjective assent cannot be relevant to the defense. The subjective will theory of duress used by some courts (and reflective of nineteenth-century theorizing) is the anomaly in contract law. The test that most plausibly fits with other contract doctrine is the Restatement's objective test, but the objective test must rest on what occurred in public, and the important part of what occurred in public in our contract law is the exchange. That

191. For reasons stated in the earlier article, see Ricks, supra note 1, at 597 n.23. I am loathe to use the Restatement: "[I]t is a scholars' summary-and in some cases, a recommendation-rather than a treatise." But the Restatement's language is widely used and often widely followed and probably is as close to representative as anything else available.

192. RESTATEMENT (SECOND) OF CONTRACTS $§ 175(1)$ (1981).

193. E.g., id. $\$ \$ 17 \mathrm{cmt}$. c, 18, 19(3), 21. 
is what the duress doctrine undercuts.

This conclusion is strengthened by the Restatement's position that some threats are only improper if the "resulting exchange is not on fair terms." 194 This has no relevance to assent directly. I have heard it related in an indirect way ("an unfair exchange suggests lack of assent"), but the simpler explanation is that, if the exchange is unfair, the substantive reasons for enforcement, one of which is that the parties had admitted up front that everyone is benefitting here so that enforcement would be equal, socially useful, and morally superior, are lacking. Enforcing the deal would then no longer prevent one party from enriching itself at another's expense, no longer save a party from reasonable detrimental reliance, and no longer be an equal enforcement of a trade of mutual promises. And there is no reason to think that the public's wealth should be used to force anyone to perform, because there probably will be no public benefit resulting. The requirement of proof of an unfair exchange is thus better understood as a direct attack on the exchange itself, and the simpler explanation is that duress is a defense because it undercuts the consideration, not the assent. ${ }^{195}$

\section{Misrepresentation or Fraud}

Misrepresentation or fraud is similar. The Restatement authors have tried to focus on assent for the purpose of describing when fraud renders a contract void:

If a misrepresentation as to the character or essential terms of a proposed contract induces conduct that appears to be a manifestation of assent by one who neither knows nor has reasonable opportunity to know of the character or essential terms of the proposed contract, his conduct is not effective as a manifestation of assent. ${ }^{196}$

But the focus on assent is only apparent. Similarly to duress, the

194. Id. § 176(2); see also id. § $176 \mathrm{cmt}$. a ("The fairness of the resulting exchange is often a critical factor in cases involving threats.").

195. Undue influence, a doctrine related to duress, operates as follows: "If a party's manifestation of assent is induced by undue influence by the other party, the contract is voidable by the victim." Id. $\S 177$. Notice the focus in this doctrine, as in duress, on inducement. Whether influence is undue depends on whether unfair persuasion occurred, and unfair persuasion depends on "whether the result was produced by means that seriously impaired the free and competent exercise of judgment." Id. $\S 177 \mathrm{cmt} \mathrm{b}$. The first factor listed by the Restatement in that determination is "the unfairness of the resulting bargain." Id. Nevertheless, this doctrine does seem more focused on the will of the party than the other contract defenses.

196. Id. § 163 . 
lynchpin is inducement by a misrepresentation, which of course undercuts inducement by the consideration. When the rule tries to shift to assent, which is not the primary issue, it becomes muddled: What is conduct that "appears to be a manifestation of assent"? How is that different than "a manifestation of assent"? This muddled language perhaps survived editing because it did not matter; assent was not at issue. What is wrong with the resulting promise is that inducement itself is undercut.

Other language from the rule indirectly makes the same point. The misrepresentation must be "as to the character or essential terms of the proposed contract." The proposed contract is an exchange, and its character or essential terms are the terms of the exchange. The comment explains that this language attempts to focus on what is called fraud in the "factum" rather than, misleadingly, the "inducement." The distinction is between the exchange itself and something peripheral to it, though, as the comments show. Being mistaken as to the identity of a party or the wealth of the other party is not enough; the misrepresentation must go to "the very nature of the proposed contract." 197 Being induced by a false exchange is not being induced by the actual exchange.

For a voidable contract, the attack on consideration is more obvious, though less direct: "If a party's manifestation of assent is induced by either a fraudulent or a material misrepresentation by the other party upon which the recipient is justified in relying, the contract is voidable ...." ${ }^{\prime 198}$ Here again the focus is on inducement, ${ }^{199}$ as in duress, and also on reliance, ${ }^{200}$ which is inducement acted upon. The test also focuses on the justification for the reliance. A misrepresentation also must be material, a word which is defined in the Restatement at least as undercutting inducement. ${ }^{201}$ As with duress, the manifestation of assent continues to exist whether the defense is successful or not; what is important is what induced it. And also as with duress, these elements focus on the reasonableness of the prima facie judgment that a promise should be enforced. After an event of fraud occurs, we can no longer be sure that enforcement prevents one party from enriching itself at another's expense, or saves a party from reasonable detrimental reliance,

\footnotetext{
197. Id. $\S 163 \mathrm{cmt} . \mathrm{a}$.

198. Id. $\S 164(1)$.

199. Id. $\S 167$.

200. Section 168 focuses on the reasonableness of the reliance, but reliance itself is inducement. Id. $\S \S 164 \mathrm{cmt} . \mathrm{c}, 168$.

201. Id. § 162(2).
} 
and we can no longer believe that the parties have admitted ex ante that the mutual promises are equal for purposes of enforcement. And there is no reason to think that the public's wealth should be used to force anyone to perform, because there probably will be no public benefit resulting.

\section{Mistake}

For mistake, the same analysis holds. The Restatement posits mutual mistake doctrine thus:

Where a mistake of both parties at the time a contract was made as to a basic assumption on which the contract was made has a material effect on the agreed exchange of performances, the contract is voidable by the adversely affected party unless he bears the risk of the mistake ....

\section{Unilateral mistake doctrine is similar in relevant ways. ${ }^{203}$}

Mistake's requirement that the mistake be "as to a basic assumption" even more explicitly focuses on the exchange. ${ }^{204}$ Many courts in fact require that the mistake go to the "substance of the consideration.", 205 I

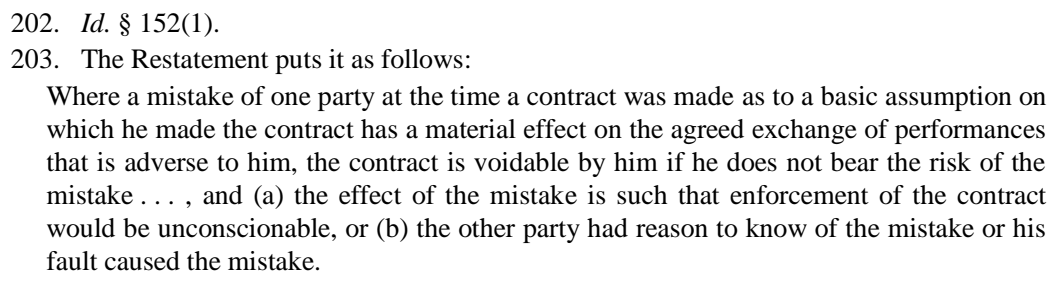

204. Id. § 152(1) (" $[\mathrm{B}]$ asic assumption on which the contract was made has a material effect on the agreed exchange of performances ....").

205. E.g., Stewart v. Ticonic Nat'l Bank, 72 A. 741, 744 (Me. 1908) (examining "whether there was a mutual mistake materially affecting the substance of that purpose and consideration"). Later courts have used other words to name the same thing, including fundamental, essential, vital, the efficient cause, the heart of the bargain, and the nature of the purchase. Ricks, supra note 86, at 666-67. The Restatement (Second) uses "basis of the bargain." RESTATEMENT (SECOND) OF CONTRACTS $\S 152$ (1981). But unilateral mistake cases still liberally rely on the phrase "substance of the consideration." See, e.g., City of Devils Lake v. St. Paul Fire \& Marine Ins. Co., 497 F. Supp. 595, 597 (D. N.D. 1980) (applying North Dakota law); Dick Corp. v. Assoc. Elec. Coop., Inc., 475 F. Supp. 15, 20 (W.D. Mo. 1979); Burge v. Fid. Bond and Mortg. Co., 648 A.2d 414, 420 (Del. 1994); Am. Bottling Co. v. Crescent/Mach I Partners, L.P., C.A. No. 09C-02-134 WCC, 2009 WL 3290729, at *4 (Del. Super. Ct. Sept. 30, 2009); First Baptist Church of Moultrie v. Barber Contracting Co., 377 S.E.2d 717, 721 (Ga. Ct. App. 1989); In re Barney, 710 A.2d 408, 411 (N.H. 1998); Iversen Constr. Corp. v. Palmyra-Macedon Cent. Sch. Dist., 539 N.Y.S.2d 858, 860 (N.Y. Sup. Ct. 1989); Gilbane Bldg. Co. v. Bd. of Trs. of State Colls., 267 A.2d 396, 398 n.3 (R.I. 1970); Arcon Constr. Co. v. State Dep't of Transp., 314 N.W.2d 303, 305 (S.D. 1982). The phrase was criticized in Lenawee Cnty. Bd. of Health v. Messerly, 331 N.W.2d 203, 209 (Mich. 1982). Here as 
have discussed this elsewhere; the origin and logic of mutual mistake lie in the undercutting of consideration, ${ }^{206}$ or, as the Restatement puts it, "the very basis for the contract," 207 or, for mutual mistake, "an unexpected material imbalance in the exchange." ${ }^{208}$ What counts as a mistake that may warrant relief shows the close relationship between mistake and consideration: "Mutual mistake applies to warrant relief (or in other words, a factual assumption is found to be basic, essential, etc.) most often when the mistake results in present impossibility or impracticability of performance, present frustration, or a gross undercutting of the equivalence of the parties' exchange." 209 The possibility of performing the promise, the promise's purpose, and its value - all of these relate directly to the consideration analysis, to the exchange and its value, and none of them to assent. At most, taking on the risk of the mistake by agreement ${ }^{210}$ removes the effect of the mistake; the essential, consideration-rebutting elements remain required and must be proved for the defense to be successful. Incidentally, the defenses of present impracticability and frustration of purpose are also an undercutting of the bargain; ${ }^{211}$ they likewise only indirectly address assent but directly attack the exchange itself, either its performance or its purpose.

well the Restatement (Second) has moved to "basic assumption." RESTATEMENT (SECOND) OF CONTRACTS $§ 153$ (1981). Some courts use merely the less specific word "material." E.g., Alaska Int'l. Constr., Inc. v. Earth Movers of Fairbanks, Inc., 697 P.2d 626, 629 (Alaska 1985).

206. See Ricks, supra note 86, at 666-72, 694-704, 715-47.

207. RESTATEMENT (SECOND) OF CONTRACTS $§ 152 \mathrm{cmt}$. a (1981).

208. Id. ch. 6, intro. note. The distinction between mutual and unilateral mistake is spoken of as one of degree - only one party is so disappointed, so the defense of unilateral mistake is "more restrictive." $I d$. However, the defense of unilateral mistake is also contingently dependent on whether the contract would be unconscionable, see $i d$. $\S 153$ (a), and unconscionability is an even more direct attack on consideration. See infra Part II.B.4.

209. Ricks, supra note 86, at 668; see also EdWIN C. MCKeaG, Mistake in Contract: A Study in COMPARATIVE JuRISPRUdENCE 77-84, 124 (1905); GeORge E. PALMER, Mistake AND UnJust ENRICHMENT 35-39 (1962); Roland R. Foulke, Mistake in the Formation and Performance of a Contract, 11 Colum. L. REv. 197, 221-23 (1911); Edward H. Rabin, A Proposed Black-Letter Rule Concerning Mistaken Assumptions in Bargain Transactions, 45 TEX. L. REV. 1273, 1288-91 (1967). The Restatement (Second) agrees, though the statement of it is somewhat hard to trace. See Ricks, supra note 86, at 670 n.34.

210. RESTATEMENT (SECOND) OF CONTRACTS § 154(a) (1981).

211. These defenses were in place by around 1800 both in Britain and the United States but in the form of action for money had and received for failure of consideration. See Ricks, supra note 86, at 704 n.206. 


\section{Unconscionability}

The relationship between unconscionability and consideration should be obvious. Unconscionability is commonly analyzed as both procedural and substantive unconscionability, i.e., bargaining naughtiness and a hard bargain. These signify problems with a supposedly bargained-for promise and consideration and, if proved, reverse whatever presumptions of policy consideration might carry with it. The doctrine of unconscionability is a direct attack on the exchange itself.

Though unconscionability doctrine relies in part on "bargaining naughtiness" or "procedural unconscionability," the sine qua non of unconscionability in the U.S. has traditionally been substantive unconscionability - that the exchange is not on fair terms. ${ }^{212}$ Courts sometimes suggest that substantive unconscionability is relevant because

212. Nearly all courts agree that substantive unconscionability - meaning an unfair bargain - is necessary. I am not going to cite all courts here, but in support please consider the following: PERILLO, supra note $8, \S 9.40 ; 8$ WILLISTON \& LORD, supra note 4, § 18.10 ("[S] inability to bargain with understanding as to the terms of an agreement (procedural unfairness) must culminate in the drafting party's exacting harsh or unreasonable terms from the other party (substantive unfairness) before the concept of unconscionability becomes applicable in the view of perhaps most jurisdictions."); FARNSWORTH, supra note 4, § 4.28. I have been clocking unconscionability cases for a number of years and not found one yet that granted relief without a harsh bargain. This is by far the express majority position. I would be very interested to be proved wrong as to whether or not such a case exists, however. Farnsworth oddly says that if "procedural unconscionability alone rises to the level of misrepresentation, duress, or undue influence ... the contract may be voidable without regard to substantive unconscionability." Id. But if those defenses actually are proved, then the contract is voidable without regard to unconscionability at all, in any of its facets. Actual cases invalidating contract terms for procedural unconscionability may exist. See, e.g., E. Ford, Inc. v. Taylor, 826 So. 2d 709, 717 (Miss. 2002) (hat tip to Professor Lonegrass for the citation, though the case is not entirely clear: the court did recite the plaintiff's arguments and the trial court's analysis that the clause at issue was also substantively unconscionable). But these are so rare as to be anomalies: "[V]ery few courts have actually invalidated contracts on the basis of purely procedural defects," Lonegrass notes, supra note 7, at 21, even though some courts now profess to be willing to grant relief on that basis if procedural unconscionability looks bad enough. Id. at 6 n.24. Professor Knapp, in a recent paper, suggests that "there are instances of a court going even beyond the 'sliding scale' approach, to find unconscionability of a contract or term based entirely on only one of the two prongs, with little or no attention paid to the other one." Charles L. Knapp, Unconscionability in American Contract Law: A Twenty-first Century Survey, UC Hastings College of Law Legal Studies Research Paper Series No. 71, 14 (2013), available at http://papers.ssrn.com/sol3/papers.cfm?abstract_id=2346498. It is true that courts say this occurs, see for example infra note 214 , but no case I know of allows an unconscionability remedy to rest entirely on the procedural side. Cases supporting Knapp's assertion on the procedural side are not apparent in his discussion. Knapp cites Iron Dynamics v. Alstom Power, Inc., 64 U.C.C. Rep. Serv. 2d (Callaghan) 201 (N.D. Ind. 2007), but that case rejected an argument solely based on procedural unconscionability. See id. The cases I know of granting relief relying only on one prong rest on substance. E.g., Maxwell v. Fid. Fin. Servs., Inc., 907 P.2d 51, 59-60 (Ariz. 1995); Brower v. Gateway 2000, Inc., 676 N.Y.S.2d 569, 574-75 (N.Y. App. Div. 1998) (a class action). 
it shows lack of assent, ${ }^{213}$ but if that were true then procedural unconscionability alone should warrant relief, and it does not. ${ }^{214}$ The language of the UCC also presumes that substantive unconscionability alone will warrant relief. ${ }^{215}$ A requirement of substantive unconscionability is precisely what one would expect if unconscionability were an argument primarily against a bargain and not against assent alone. The simpler explanation of the unconscionability defense is that substantive unconscionability is required because the doctrine is not an attack on assent but on consideration.

Unconscionability as a defense may slowly move away from its dependency on a finding of a hard bargain. ${ }^{216}$ This would throw the logic of the formation defenses into some disarray. What need would we have of duress, fraud, or mistake if something like but less than any of thesewithout any hard bargain at all-would render a contract voidable? On the other hand, it matters very little which defense we use if all of them are a re-examination of the bargain.

\section{CONCLUSIONS}

Each of the formation defenses arose before we had assent doctrines. At the time, a prima facie case was made out by showing promise, consideration, and breach. The defenses do not show that no promise was made, or that breach did not occur. They were instead aimed at taking away the consideration, or that which made consideration an element of a prima facie case. Consideration, with the promise, was the ground for the action. The defenses still function the same way today. The suggestion that assent is all that is at issue here may make one feel relatively contemporary, but it fails to explain why contract defenses defend, just as it fails to explain why we hang onto the consideration doctrine after four-and-a-half centuries.

Understanding consideration's role in justifying the formation

213. See, e.g., Lonegrass, supra note 7, at 22-25 (reporting judicial opinions).

214. The Maxwell case from Arizona, Maxwell v. Fid. Fin. Servs., Inc., 907 P.2d 51 (Ariz. 1995), asserted that some courts hold either procedural or substantive unconscionability alone to be sufficient. $I d$. at $58 \&$ n.3. But every case cited by that court to prove the point held on substantive unconscionability alone, not procedural. See also supra note 212.

215. U.C.C. $\$ 2-302(1)$ ("If the court as a matter of law finds the contract or any clause of the contract to have been unconscionable at the time it was made ....”); id. § 2-719(3) (naming a clause which the code declares "prima facie unconscionable" without any reference to procedural matters); see also Maxwell, 907 P.2d at 59 (accepting this argument).

216. See the judicial language addressing this issue at Lonegrass, supra note 7, at 6 n.24. 
defenses should influence the way contract law is litigated, taught, and theorized. What was true with regard to consideration's role in formation elements ${ }^{217}$ is true for consideration's role in formation defenses. As discussed in Assent Is Not an Element of Contract Formation, focusing on consideration emphasizes that what is at issue in each breach of contract case is the enforcement of a promise. Belying our loose talk about agreement and assent, the contract formation doctrines themselves, when they function, operate almost exclusively on a promise, consideration for that promise, and defenses which undercut that consideration. ${ }^{218}$ All the doctrines address the enforceability of one single promise at a time, not an agreement. Consideration is still the touchstone of promise enforcement, because it contains the plaintiff's policy statement supporting why the law should in the first place take any account of the defendant's promise and breach. When students learn contract formation, they will therefore understand best how the doctrines fit together and how they function if the students study promise and consideration first. Finally, theory that grounds the formation defenses solely on assent will miss the point. The defenses address more than assent; they address the consideration.

217. See Ricks, supra note 1, Part IV.B.

218. Id. at $653-55$. 